\title{
\#USGS
}

\section{Documentation of a Spreadsheet for Time-Series Analysis and Drawdown Estimation}
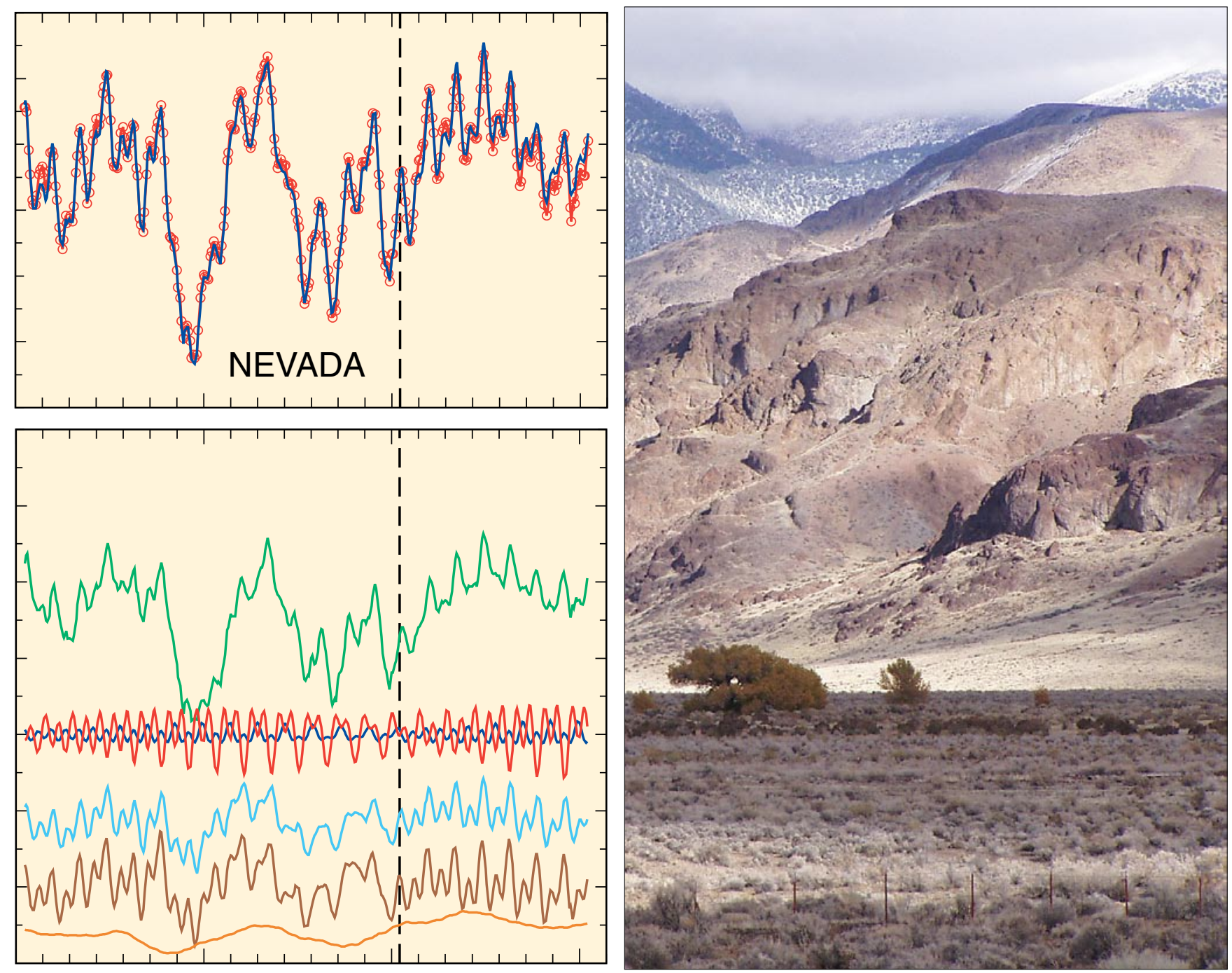

Prepared in cooperation with the

Southwest Florida Water Management District and

U.S. Air Force, Aeronautic Systems Command

\section{Scientific Investigations Report 2006-5024}

U.S. Department of the Interior

U.S. Geological Survey 



\section{Documentation of a Spreadsheet for Time-Series Analysis and Drawdown Estimation}

By Keith J. Halford

Prepared in cooperation with the

Southwest Florida Water Management District and

U.S. Air Force, Aeronautic Systems Command

Scientific Investigations Report 2006-5024

U.S. Department of the Interior

U.S. Geological Survey 


\section{U.S. Department of the Interior \\ P. Lynn Scarlett, Acting Secretary}

\section{U.S. Geological Survey \\ P. Patrick Leahy, Acting Director}

Use of trade, product, or firm names in this report is for identification purposes only and does not constitute endorsement by the U.S. Geological Survey.

Carson City, Nevada, 2006

For additional information write to:

U.S. Geological Survey

Director, USGS Nevada Integrated Science Center

333 West Nye Lane, Room 203

Carson City, NV 89706-0866

Email: GS-W-NVpublic-info@usgs.gov

URL: http://nevada.usgs.gov/

For more information about the USGS and its products:

Telephone: 1-888-ASK-USGS

World Wide Web: http://www.usgs.gov/

Although this report is in the public domain, permission must be secured from the individual copyright owners to reproduce any copyrighted materials contained within this report.

Scientific Investigations Report 2006-5024 


\section{Contents}

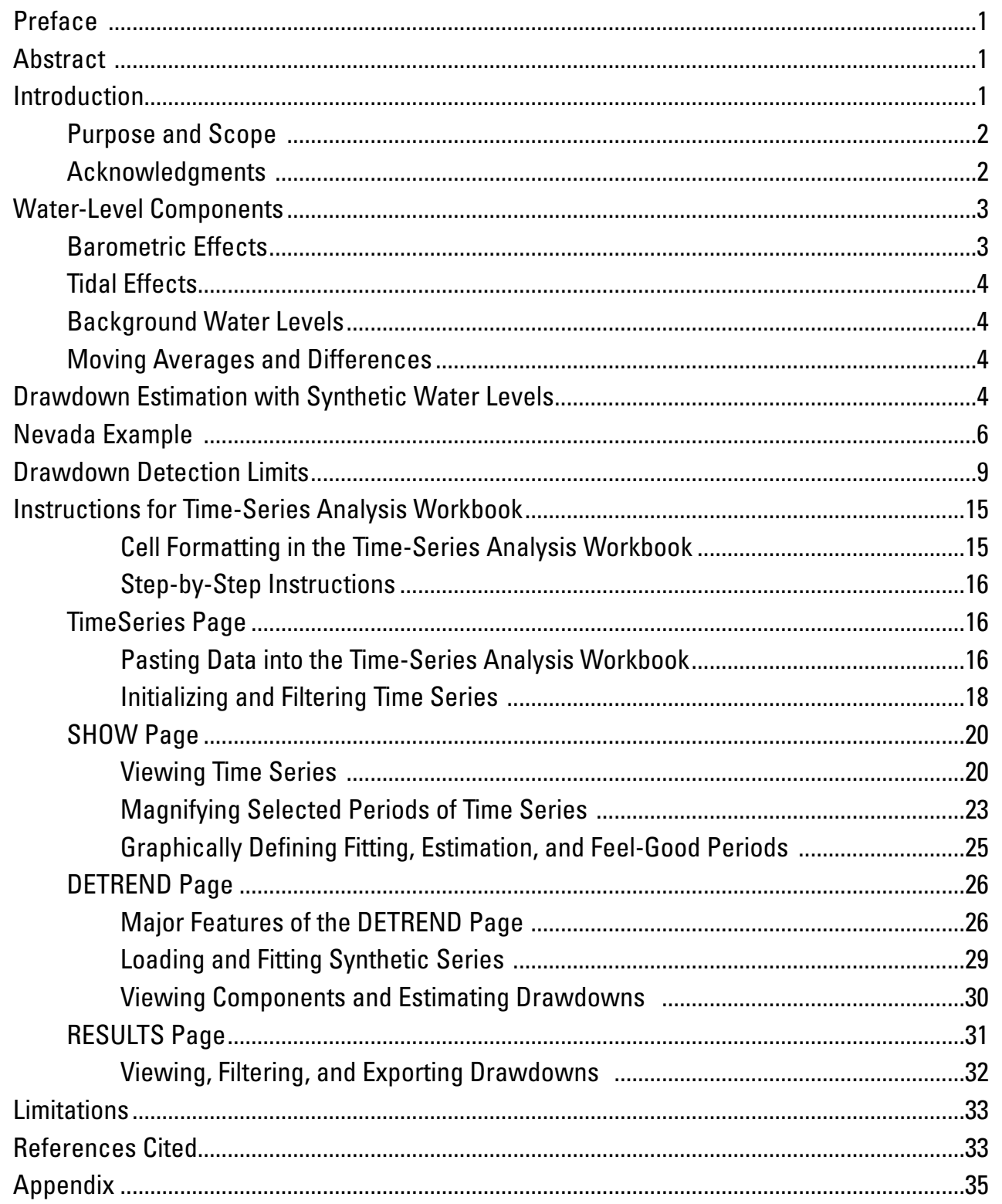




\section{Figures}

Figure 1. Daily precipitation, ground-water levels, barometric change, and earth tide at Air Force Plant 6, Marietta, Georgia, April 22 to May 28, 2004............................................... 3

Figure 2. Two time series with different collection frequencies and sampling times.......................5

Figure 3. Example fitting period, April 17 to 30, 1997, and an estimation period, May 1 to 5, 1997... 5

Figure 4. Barometric change, earth tide, and ground-water levels in wells TR-3 and SM-23-1 in the Amargosa Desert, Nevada, April 17 to May 1, 1997. ............................................... 6

Figure 5. Improvement of synthetic water level for well SM-23-1, April 17 to May 1, 1997, by sequentially analyzing barometric change, earth tide, and water levels in well TR-3...... 7

Figure 6. Example of drawdown filter, sub-periods, and averaging periods..................................... 8

Figure 7. Water levels in wells HYPO-1, HYPO-5, and modified TR-3 and drawdowns in wells HYPO-1 and HYPO-5, April 26 to May 11, 1997. 9

Figure 8. Water levels in well HYPO-5 and Theis, raw, and filtered drawdowns, April 26 to May 11, 1997. 10

Figure 9. Fitting and prediction error comparison sites. 10

Figure 10. Measured water levels, synthetic water levels, and water-level components in well SM-23-1, Nevada, during a 14-day fitting period and a 7-day prediction period that began May 1, 1997

Figure 11. Fitting and prediction errors for five synthetic water levels in well sct4 in Georgia, with a 7-day prediction period that begins May 27, 2004.

Figure 12. Measured and synthetic water levels at sites sct4 in Georgia, Sister Lake in Louisiana, and R30AvPk in Florida during 14-day fitting periods and 7-day prediction periods.

Figure 13. Example of Excel forms for changing security settings. ……...................................... 15

Figure 14. Example of TimeSeries page with data entered. ............................................................ 16

\section{Tables}

Table 1. Sites with water-level time series that were used to create synthetic water levels ......... 8

Table 2. Ratios of prediction-to-fitting errors, prediction periods, water-level ranges, and prediction-error ranges at sites in Florida, Georgia, Louisiana, and Nevada 12

\section{Appendix}

Step-by-Step Instructions for Nevada Example 


\section{Conversion Factors and Datums}

\begin{tabular}{lcl}
\hline \multicolumn{1}{c}{ Multiply } & By & \multicolumn{1}{c}{ To obtain } \\
\hline inch (in.) & 25.4 & millimeter $(\mathrm{mm})$ \\
foot $(\mathrm{ft})$ & 0.3048 & meter $(\mathrm{m})$ \\
foot per day $(\mathrm{ft} / \mathrm{d})$ & 0.3048 & meter per day $(\mathrm{m} / \mathrm{d})$ \\
foot squared per day $\left(\mathrm{ft}^{2} / \mathrm{d}\right)$ & 0.0929 & meter squared per day $\left(\mathrm{m}^{2} / \mathrm{d}\right)$ \\
gallon per minute $(\mathrm{gal} / \mathrm{min})$ & 0.06308 & liter per second $(\mathrm{L} / \mathrm{sec})$ \\
mile (mi) & 1.609 & kilometer $(\mathrm{km})$ \\
\hline
\end{tabular}

${ }^{1}$ Expresses transmissivity. An alternative way of expressing transmissivity is cubic foot per day per square foot times foot of aquifer thickness $\left[\left(\mathrm{ft}^{3} / \mathrm{d}\right) \mathrm{ft}^{2}\right] \mathrm{ft}$.

Horizontal coordinate information is referenced to the North American Datum of 1927 (NAD 27). Vertical coordinate information is referenced to the National Geodetic Vertical Datum of 1929 (NGVD 29). Altitude, as used in this report, refers to distance above the vertical datum. 


\section{Documentation of a Spreadsheet for Time-Series Analysis and Drawdown Estimation}

\author{
By Keith J. Halford

\section{Preface}

This report documents a spreadsheet that has been developed for analyzing time series with an emphasis on estimating drawdowns during aquifer tests by removing extraneous waterlevel changes at observation wells resulting from barometric pressure changes, earth tides, or regional water-level trends. The spreadsheet was developed for Microsoft Excel version 9.0 or higher. Use of trade names does not constitute endorsement by the U.S. Geological Survey (USGS). The spreadsheet has been tested for accuracy using datasets from different aquifer tests and FORTRAN solutions of dry earth tide and gravity tide. If users find or suspect errors, please contact the USGS.

Every effort has been made by the USGS or the United States Government to ensure that the spreadsheet is error free. Despite our best efforts, the possibility exists that errors exist in the spreadsheet. The distribution of the spreadsheet does not constitute any warranty by the USGS, and no responsibility is assumed by the USGS in connection therewith.

\section{Abstract}

Drawdowns during aquifer tests can be obscured by barometric pressure changes, earth tides, regional pumping, and recharge events in the water-level record. These stresses can create water-level fluctuations that should be removed from observed water levels prior to estimating drawdowns. Simple models have been developed for estimating unpumped water levels during aquifer tests that are referred to as synthetic water levels. These models sum multiple time series such as barometric pressure, tidal potential, and background water levels to simulate non-pumping water levels. The amplitude and phase of each time series are adjusted so that synthetic water levels match measured water levels during periods unaffected by an aquifer test. Differences between synthetic and measured water levels are minimized with a sum-of-squares objective function. Root-mean-square errors during fitting and prediction periods were compared multiple times at four geographically diverse sites. Prediction error equaled fitting error when fitting periods were greater than or equal to four times prediction periods.

The proposed drawdown estimation approach has been implemented in a spreadsheet application. Measured time series are independent so that collection frequencies can differ and sampling times can be asynchronous. Time series can be viewed selectively and magnified easily. Fitting and prediction periods can be defined graphically or entered directly. Synthetic water levels for each observation well are created with earth tides, measured time series, moving averages of time series, and differences between measured and moving averages of time series. Selected series and fitting parameters for synthetic water levels are stored and drawdowns are estimated for prediction periods. Drawdowns can be viewed independently and adjusted visually if an anomaly skews initial drawdowns away from 0 . The number of observations in a drawdown time series can be reduced by averaging across user-defined periods. Raw or reduced drawdown estimates can be copied from the spreadsheet application or written to tab-delimited ASCII files.

\section{Introduction}

Barometric pressure variations, earth tides, regional pumping, and recharge events commonly affect water levels in observation wells (Jacob, 1940; Ferris, 1951; Melchior, 1964; Gregg, 1966; Bredehoeft, 1967; Clark, 1967). Water levels typically fluctuate daily between 0.1 and $0.4 \mathrm{ft}$ because of barometric pressure changes and tides (Merritt, 2004). Water levels can fluctuate more than a foot during a week due to large weather systems that change barometric pressure. Water levels fluctuate seasonally more than $30 \mathrm{ft}$ where prevalent agricultural pumpage occurs, such as in central Florida. Individual recharge events have caused water levels in unconfined aquifers to rise more than $2 \mathrm{ft}$ and decline at rates of $0.1 \mathrm{ft} / \mathrm{d}$ afterwards (O'Reilly, 1998).

Hydraulic properties of aquifer systems have been determined by analyzing periodic water-level fluctuations. Rock compressibility and porosity have been related to barometric loading (Jacob, 1940; Rojstaczer and Agnew, 1989). Specific storage has been estimated by analyzing water-level fluctuations that were induced by earth and ocean tides (Bredehoeft, 1967; Robinson and Bell, 1971; van der Kamp and Gale, 1983; Hsieh and others, 1988). Earth-tide, ocean-tide, and barometric fluctuations have been analyzed exhaustively to estimate lateral hydraulic diffusivity (Jacob, 1940; Ferris, 1951; van der Kamp, 1972; Jiao and Tang, 1999; Li and Jiao, 2001; Merritt, 2004). Pneumatic diffusivity has been estimated by exploiting transient, barometric pressure differences between a well in an unconfined aquifer and the surrounding 
unsaturated zone (Weeks, 1979; Rojstaczer, 1988; Rojstaczer and Riley, 1990).

Pumping-induced drawdowns are analyzed to estimate hydraulic properties and are the difference between observed water levels and what water levels would have been in the absence of pumping. Periodic water-level fluctuations and trends typically can be ignored where drawdowns are great and pumping periods are short. Daily fluctuations of 0.5 $\mathrm{ft}$ will not obscure drawdowns of more than $5 \mathrm{ft}$. Regional water-level declines of $0.05 \mathrm{ft} / \mathrm{d}$ typically will not alter hydraulic property estimates when pumping periods are less than a few days.

Periodic water-level fluctuations can obscure the measurement of interest during aquifer tests and in most other hydrologic applications. Water-level changes other than those from planned pumping are considered undesirable when analyzing an aquifer test and should be removed prior to analysis. These fluctuations substantially affect drawdown estimates where the extraneous water-level changes are of equal or greater magnitude. Tidal water-level fluctuations of several feet in coastal areas also complicate the construction of potentiometric surfaces (Gregg, 1966). Errors in water level of a foot can reverse apparent flow directions where the range of water levels is only a few feet (Erskine, 1991).

Barometric water-level fluctuations typically are removed by relating these periodic fluctuations to nearby air-pressure changes with a barometric efficiency (Jacob, 1940; Clark, 1967; Furbish, 1991). Barometric efficiency is the ratio of change in water level to change in barometric pressure (Ferris and others, 1962). Barometric effects are removed by subtracting air-pressure change times barometric efficiency from a measured water level. Tidal fluctuations also are described and removed with tidal efficiencies (Ferris and others, 1962; van der Kamp and Gale, 1983). A tidal efficiency is the ratio of change in water level to change in an ocean tide gage or theoretical earth tide (Bredehoeft, 1967; Erskine, 1991).

Regional water-level trends have been extrapolated from antecedent data to estimate drawdown during aquifer tests (Ferris and others, 1962). A linear trend can approximate regional water-level changes or recovery from previous pumping at an aquifer-test site but has limited utility after a couple of days. Regional pumping and a rainfall event during a 3-day aquifer test in Pennsylvania caused water-level changes to be poorly predicted by a linear trend that obscured drawdowns of less than $1 \mathrm{ft}$ (Risser and Bird, 2003).

Water-level changes in the absence of pumping have been estimated with water levels from individual wells beyond the influence of an aquifer test (Kruseman and DeRidder, 1990). Water-level changes at an observation well and a background well in Volusia County, Florida, were related with doublemass curves (Rutledge, 1985). Drawdowns were less than 0.2 $\mathrm{ft}$ and were not successfully differentiated from natural waterlevel fluctuations in the surficial aquifer. Drawdowns also were estimated with linear regressions between water-level changes at observation wells and a background well (Halford, 1997). Drawdowns of $0.2 \mathrm{ft}$ during a 2-day test in northeast- ern Florida were detected, but drawdown detection was limited to $0.1 \mathrm{ft}$.

Simple spreadsheet-based models are proposed for estimating water-levels unaffected by pumping during aquifer tests. The summation of multiple time series such as barometric pressure, tidal potential, and background water levels can simulate non-pumping water levels. These simulated water levels will be referred to as synthetic water levels. Synthetic water levels are needed because water levels unaffected by pumping cannot be measured during an aquifer test. The amplitude and phase of each time series component included in the summation are adjusted so that synthetic water levels match measured water levels during a non-pumping period. The synthetic water-level approach supplants barometric efficiency, tidal efficiency, linear trends, and other correction methods commonly applied.

Drawdowns of less than $0.1 \mathrm{ft}$ can be detected with the synthetic water-level approach, which greatly expands the volume of aquifer investigated by an aquifer test. The radius of investigation in Theis-like aquifers with transmissivities greater than $10,000 \mathrm{ft}^{2} / \mathrm{d}$ will double at a minimum and can increase more than ten times by reducing drawdown detection limits from 0.5 to $0.05 \mathrm{ft}$. Vertical leakances of confining units can be estimated more reliably by reducing the limit of drawdown detection.

\section{Purpose and Scope}

The purpose of this report is to document an approach for estimating drawdowns with simple water-level models that sum multiple time series. A method for fitting these models to measured water-levels by adjusting the amplitude and phase of each series is reported. An approach for reducing drawdown measurements by averaging across user-specified intervals is reported. These approaches and methods are implemented in a spreadsheet application. This spreadsheet is compatible with Microsoft Excel versions 9.0 or higher and requires basic knowledge of Excel. Use and applicability of this software is documented in this report. The hydrologic concepts and methods used in the data processing also are described briefly.

\section{Acknowledgments}

This study was supported jointly by the Southwest Florida Water Management District and U.S. Air Force, Aeronautic Systems Command. Robert Peterson of the Southwest Florida Water Management District and the supportive personnel of the U.S. Air Force, Aeronautic Systems Command, provided valuable assistance. Data sets from Florida, Georgia, Louisiana, and Nevada were provided by Dann Yobbi, Gerard Gonthier, Chris Swarzenski, and Joe Fenelon, respectively, of the U.S. Geological Survey. Finally, the author is grateful to Paula Cutillo of the National Park Service and Randell Laczniak, Joe Fenelon, Eve Kuniansky, and Devin Galloway 
of the U.S. Geological Survey for materially improving the drawdown-estimation spreadsheet and report.

\section{Water-Level Components}

Barometric pressure, tidal potential, background water levels, stream stage, and any other time series are potential components in a water-level record. The relevant components can be selected where a relation in the water-level record is expected. For example, a relation between barometric pressure and water levels in well sct4 is not obvious (fig. 1), but a relation is expected. A barometric pressure component should be included to test if barometric pressure improves a synthetic water-level series of well sct 4 .

\section{Barometric Effects}

Barometric changes cause greater water-level fluctuations in deeper, confined aquifers where rock matrix absorbs more of the atmospheric load (Merritt, 2004). Fluctuations increase because pressure instantly affects water levels in wells while a stiffer rock matrix transfers little of the increased atmospheric load to the confined water column. Atmospherically induced water-level fluctuations typically are less than $0.2 \mathrm{ft}$ during a day. Large barometric pressure changes from regional storms can cause water-level fluctuations of about $1 \mathrm{ft}$ during a week.

Barometric changes also measurably affect water levels in unconfined aquifers (Weeks, 1979). Pressure changes do not propagate instantaneously through the unsaturated zone because air is highly compressible. The relatively low pneumatic diffusivity of the unsaturated zone creates substantial lags between atmospheric and water-level changes. Uncon-

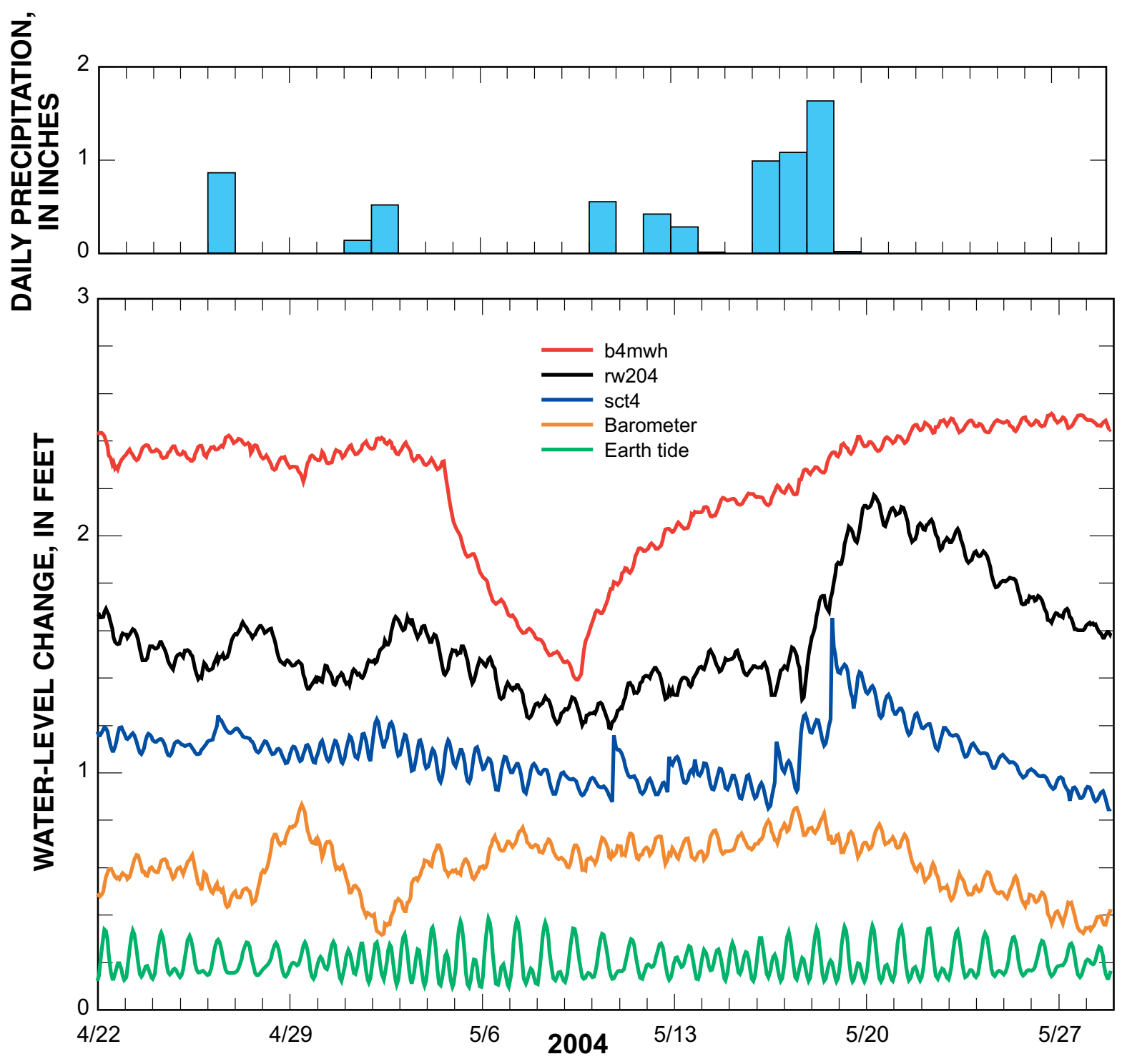

Figure 1. Daily precipitation, ground-water levels, barometric change, and earth tide at Air Force Plant 6, Marietta, Georgia, April 22 to May 28, 2004. 
fined water-level fluctuations can approach the magnitude of confined water-level fluctuations as the depth to water exceeds $500 \mathrm{ft}$.

\section{Tidal Effects}

Tides result from changes in gravitational forces as the relative positions of sun, moon, and earth change. The diurnal rise and fall of ocean levels are the most common manifestation of varying gravitational forces and are referred to as ocean tides. Ocean tides affect ground-water levels through direct head changes in an aquifer or as loads applied through a confining unit (Merritt, 2004). Ocean tide effects are better approximated with a nearby tidal gage that also incorporates wind and coastal geometry effects in addition to direct gravitational forcing.

Tidal forces also distort the crust of the earth which creates water-level fluctuations in mid-continent wells (Bredehoeft, 1967; Marine, 1975; Hanson and Owen, 1982; Narasimhan and others, 1984). Earth tides periodically deform (dilate and compress) the skeleton of the aquifer system, changing the porosity and causing measurable water-level fluctuations of as much as $0.1 \mathrm{ft}$ or more in wells penetrating aquifers with small storage coefficients (fig. 1). Coupling between the mechanical deformation and the fluid filling the secondary porosity amplifies water-level response in wells hydraulically connected to the secondary-porosity features. The presence of secondary porosity typically renders the formation more compliant to imposed stresses depending on orientation of the fractures or faults with respect to the principal component directions of the imposed stress. The theoretical crustal strain tensors resulting from the two principal lunar daily and semidiurnal tides $\left(\mathrm{O}_{1}\right.$ and $\mathrm{M}_{2}$ ) are largely horizontal and orthogonal to one another. Subvertical fractures with azimuths oriented perpendicular to the strain tensor for a particular tide tend to amplify the strain and thereby the water-level response (Bower, 1983).

Two theoretical earth tides are included as internal functions in the drawdown estimation spreadsheet. The first earth tide function computes the areal strain tide in parts per billion (ppb), and the second function computes the gravity tide in microgals ( $\mu$ gal) downward normal to the Earth ellipsoid (Harrison, 1971).

\section{Background Water Levels}

Recharge events and regional pumping are identifiable stresses that typically affect large areas but are not predicted easily with independent time series such as barometric change and tidal potential. Recharge events and regional pumping stresses create similar water-level changes in multiple wells over areas of many square miles. Water levels in wells sufficiently removed from an aquifer test can simulate these regional stresses and any other unidentified stresses. Water levels in these remote wells will be referred to as background water levels.
Background water levels can be more effective correctors than independent barometric and tidal time series even where only barometric and tidal stresses are significant. Barometric forcing through the unsaturated zone lags behind because of the low permeability of unsaturated rock relative to an open well (Weeks, 1979). The complex relation between barometric pressure and water levels in a well are explained poorly with a barometric efficiency where the unsaturated zone is thick. Background water levels from another well of similar construction better approximate this relation. Likewise, rock properties and fracture orientation in an aquifer control tidal water-level fluctuations as much as dry earth tide. Water levels from background wells can better approximate the rocktide interaction than just dry earth tide.

\section{Moving Averages and Differences}

Amplitudes of diurnal water-level fluctuations in wells frequently differ from lower frequency changes such as frontal barometric changes. Frequency dependent differences in water-level fluctuations exist between wells because of differences in well construction and aquifer properties. Diurnal water-level fluctuations will be less where communication between well and aquifer is impeded and wellbore storage is increased. Poorly developed wells with large casing diameters and short screens damp high frequency water-level fluctuations. Low transmissivity aquifers with large storage coefficients also will damp water-level fluctuations.

Low frequency signals are separated from diurnal waterlevel fluctuations with moving averages of the original time series in the spreadsheet. Water levels typically are averaged over 12-hour or 24-hour periods, but any averaging periods can be specified. High frequency signals are differences between the raw time series and the moving averages. Three time series: raw, moving average, and differences, are available for each water-level series.

\section{Drawdown Estimation with Synthetic Water Levels}

Drawdowns are differences between measured and synthetic water levels that are created for each observation well. Multiple time series such as barometric change, earth tide, and background water levels are specified as components of a synthetic water-level series. Synthetic water levels are modified by adjusting the amplitude and phase of each component. The synthetic water level at time, $\mathrm{t}$, is

$$
S W L(t)=C_{0}+C_{1}\left(t-t_{0}\right)+\sum_{i=1}^{n} a_{i} V_{i}\left(t+\phi_{i}\right)
$$




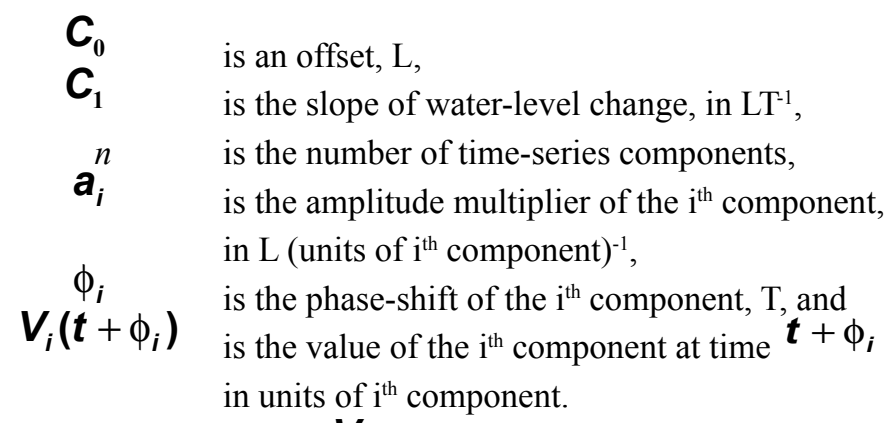

Each time series, $\boldsymbol{V}_{\boldsymbol{i}}$, is a smooth function because values are interpolated between consecutive data pairs. Interpolation allows data to be collected at variable intervals within a time series. This also means collection frequencies can differ between time series and do not need to be synchronized (fig. 2).

The amplitude and phase of each component are adjusted so synthetic water levels match measured water levels during

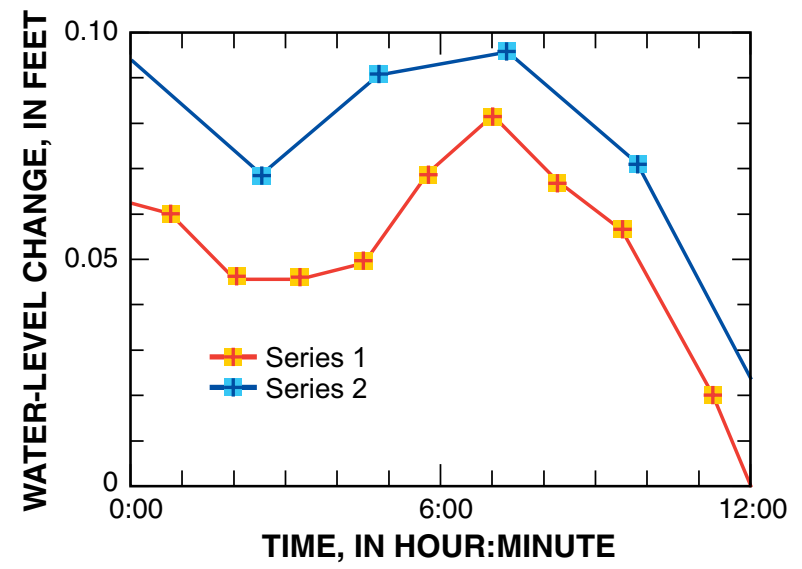

Figure 2. Two time series with different collection frequencies and sampling times. periods unaffected by an aquifer test. These periods will be referred to as fitting periods. A sum-of-squares of differences between synthetic and measured water levels is minimized to estimate amplitudes and phases. Root-mean-square (RMS) error is reported instead of sum-of-squares so error and the range of fluctuation can be compared easily.

Amplitude and phase estimates typically are non-unique, which is not important for drawdown estimation. Synthetic water levels are the important result, not parameter estimates. Amplitude estimates remain unique until two or more of the components are highly correlated. Phase estimates are nonunique regardless of the number of components because many local minima exist. Adjustment of the phase of each component is limited to a user-defined range. Sensitivity should be tested with multiple initial phase estimates because synthetic water-level estimates frequently can be improved.

Fitting periods should coincide with non-testing conditions where all stresses other than pumping for an aquifer test affect water levels. Ideally, a fitting period will be immediately antecedent to an aquifer test. Differences between an antecedent fitting period and an estimation period are compared easily because water-level changes are greatest at the beginning of an aquifer test (fig. 3). A fitting period can occur after an aquifer test, but synthetic water-level will not simulate measured water levels as well if water levels are still recovering or background conditions have changed.

Components of the synthetic water-level record are selected by trial-and-error. Time series that mimic the waterlevel record to be analyzed should be selected (fig. 4). Background water levels frequently best approximate the water levels to be analyzed. Irrelevant components make the fitting process take longer but do not degrade the predictive capacity of synthetic water levels. The amplitude of an irrelevant component will approach zero, which causes this component to negligibly affect the synthetic water levels.

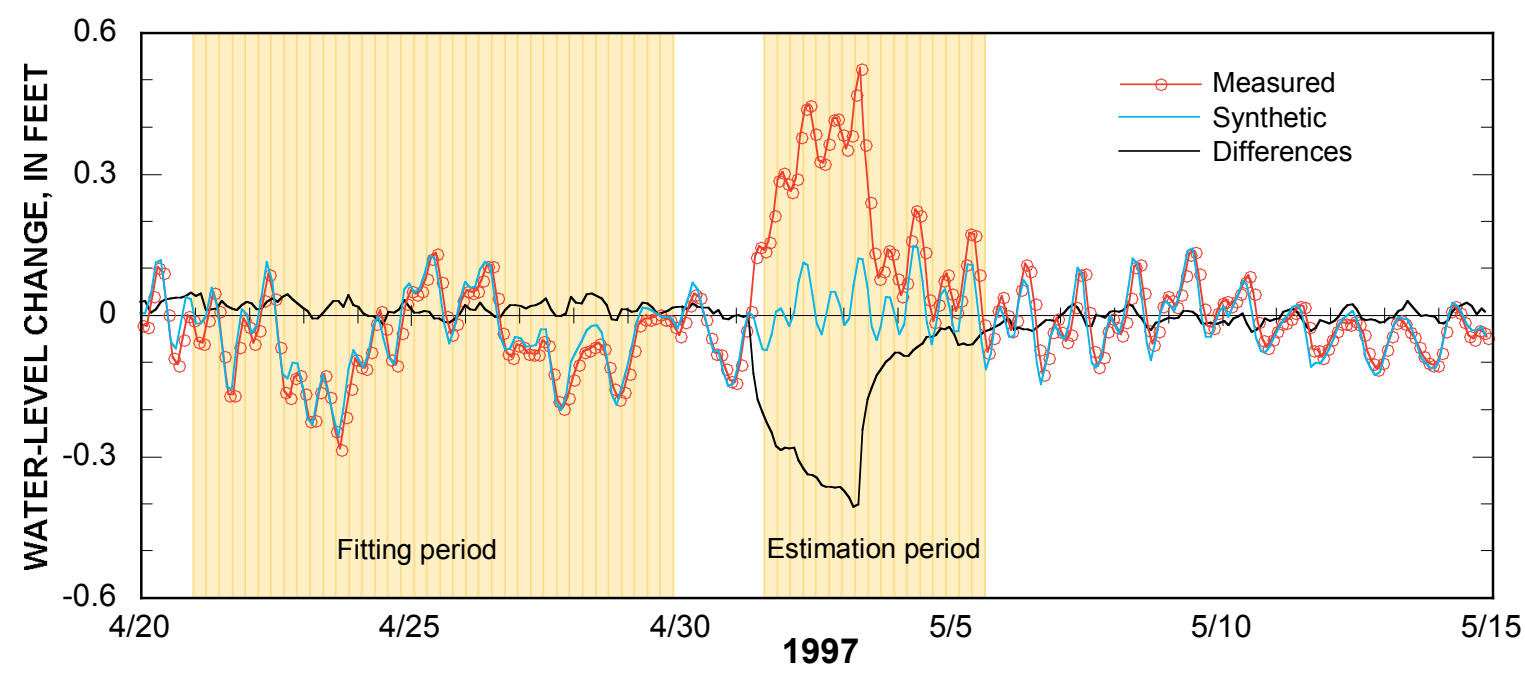

Figure 3. Example fitting period, April 17 to 30, 1997, and an estimation period, May 1 to 5, 1997. 


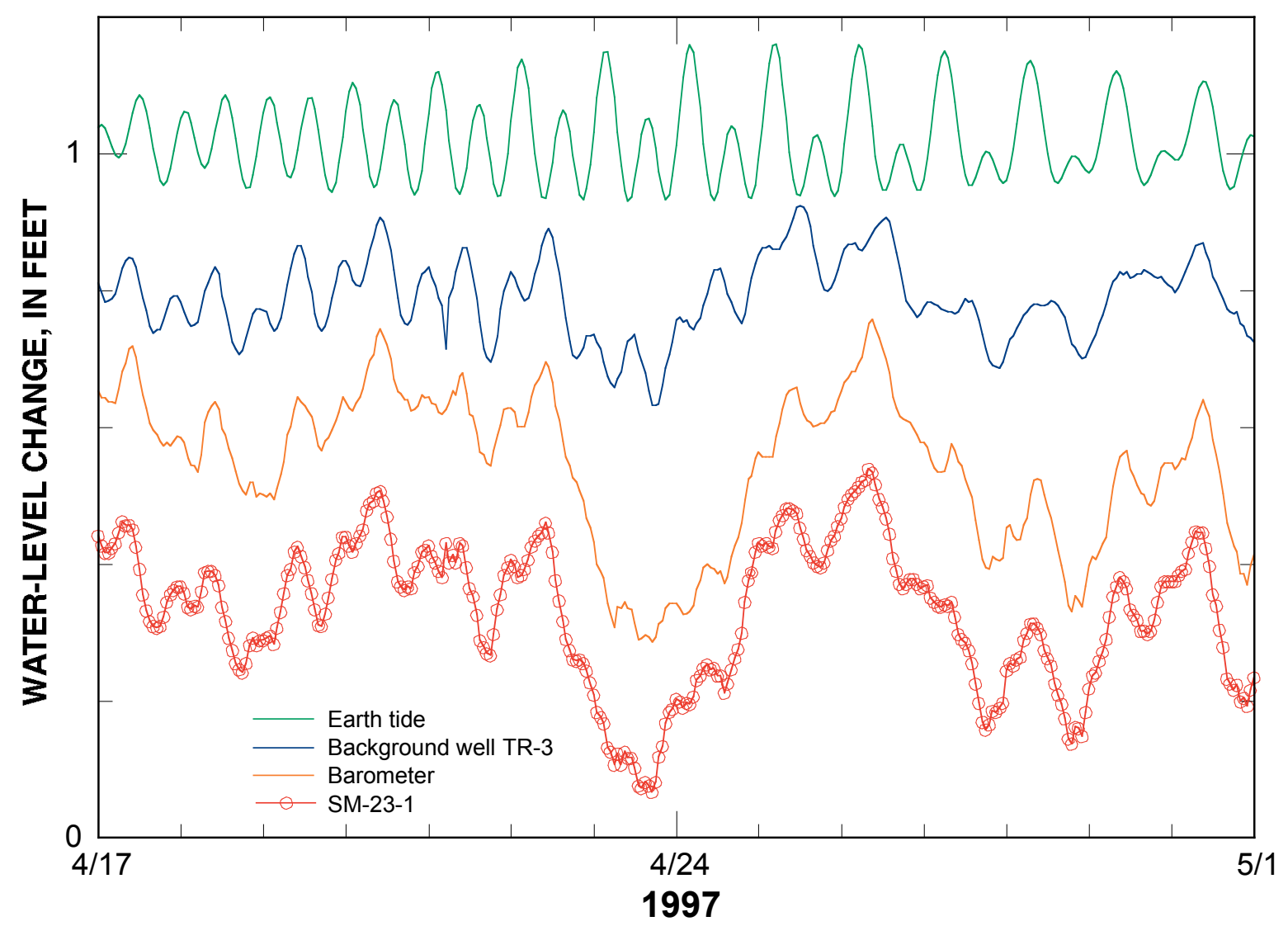

Figure 4. Barometric change, earth tide, and ground-water levels in wells TR-3 and SM-23-1 in the Amargosa Desert, Nevada, April 17 to May 1, 1997.

The significance of components can be tested by sequentially adding each component to the synthetic water-level series (fig. 5). For example, a synthetic water-level series for well SM-23-1 is simulated with barometric change, earth tide, and water levels in well TR-3 (table 1). Wells TR-3 and SM-23-1 are $15 \mathrm{mi}$ apart and are both open to the same highly transmissive carbonate aquifer in southern Nevada. Barometric change approximates much of the observed water-level fluctuations in well SM-23-1 with an $\mathrm{r}^{2}$ of 0.89 and a RMS error of $0.035 \mathrm{ft}$. Addition of an earth-tide series marginally improves the synthetic water-levels with an $\mathrm{r}^{2}$ of 0.92 . Addition of the background well TR-3 greatly improves the match between measured and synthetic water levels with an $\mathrm{r}^{2}$ greater than 0.99 and a RMS error less than $0.01 \mathrm{ft}$ (fig. 5).

Measured water levels are subtracted from synthetic water levels to estimate drawdowns in each observation well. The initial difference between measured and synthetic water levels at the beginning of an aquifer test is assumed to be zero. Drawdowns can be adjusted visually if discrete anomalies skew initial drawdowns away from 0 . Adjustment of the minimum drawdown in a series to equal 0 is reasonable if waterlevel rises were caused by the "Noordbergum effect" (Verruijt, 1969; Wolff, 1970).
The number of observations in a drawdown time series can be reduced by averaging across user-defined periods (fig. 6). Drawdown and recovery in a well can be defined quite well with less than 100 observations. Large data sets should be reduced to ease aquifer-test analysis. Selective data reduction also controls the implicit weighting of solutions toward greater numbers of observations. Raw drawdowns are reduced by averaging to smooth high frequency water-level fluctuations (fig. 6).

\section{Nevada Example}

An example was created by adding drawdown and recovery from a hypothetical aquifer test in a confined aquifer to the time series from well TR-3. Pumping responses were simulated with a Theis (1935) solution with a transmissivity of $20,000 \mathrm{ft}^{2} / \mathrm{d}$ and a storage coefficient of 0.0005. Pumping started 5/1/1997 8:00 and a discharge of $100 \mathrm{gal} / \mathrm{min}$ was maintained over a 48-hour period. Pumping ceased 5/3/1997 8:00 and recovery was simulated until residual drawdown was less than $0.01 \mathrm{ft}$ (fig. 7). 


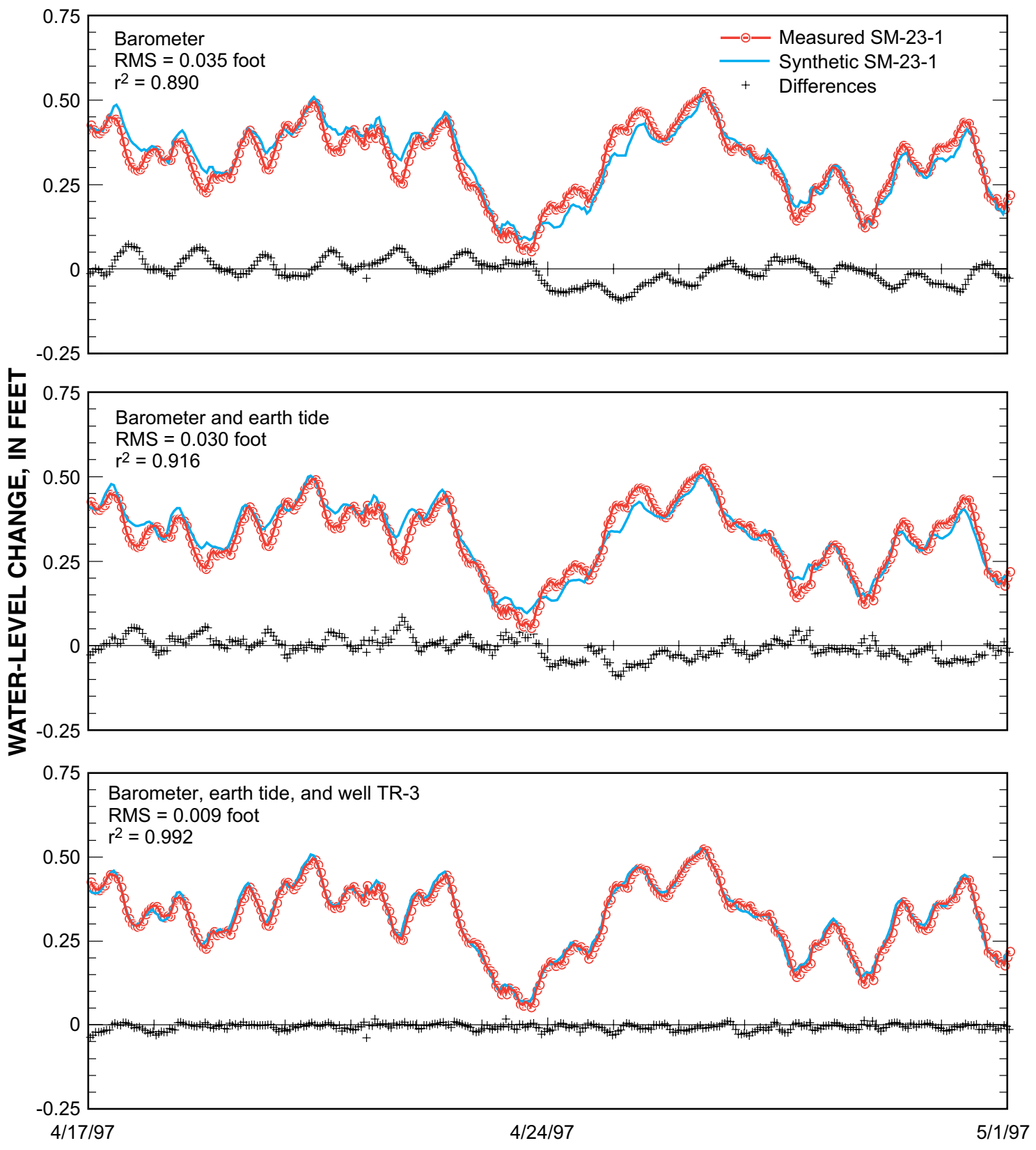

Figure 5. Improvement of synthetic water level for well SM-23-1, April 17 to May 1, 1997, by sequentially analyzing barometric change, earth tide, and water levels in well TR-3. 
Table 1. Sites with water-level time series that were used to create synthetic water levels

\begin{tabular}{|c|c|c|c|c|c|c|c|c|}
\hline State & $\begin{array}{l}\text { USGS site } \\
\text { identifier }\end{array}$ & Site name & Latitude & Longitude & $\begin{array}{c}\text { Altitude } \\
\text { (feet) }\end{array}$ & $\begin{array}{l}\text { Well } \\
\text { depth } \\
\text { (feet) }\end{array}$ & $\begin{array}{l}\text { Depth of } \\
\text { top } \\
\text { opening } \\
\text { (feet) }\end{array}$ & $\begin{array}{c}\text { Depth of } \\
\text { bottom } \\
\text { opening } \\
\text { (feet) }\end{array}$ \\
\hline Florida & 272728081484701 & $\mathrm{R} 20 \mathrm{AvPk}$ & $27^{\circ} 27^{\prime} 28^{\prime \prime}$ & $81^{\circ} 47^{\prime} 47^{\prime \prime}$ & 67 & 1,266 & 380 & 1,266 \\
\hline Florida & 272714081545901 & $\mathrm{R} 31 \mathrm{AvPk}$ & $27^{\circ} 27^{\prime} 14^{\prime \prime}$ & $81^{\circ} 54^{\prime} 59^{\prime \prime}$ & 78 & 1,152 & 460 & 1,152 \\
\hline Florida & 271757081493002 & $\mathrm{R} 26 \mathrm{AvPk}$ & $27^{\circ} 17^{\prime} 57^{\prime \prime}$ & $81^{\circ} 40^{\prime} 39^{\prime \prime}$ & 75 & 1,320 & 580 & 1,320 \\
\hline Florida & 272012081482501 & Marshall & $27^{\circ} 20^{\prime} 12^{\prime \prime}$ & $81^{\circ} 48^{\prime} 25^{\prime \prime}$ & 63 & 178 & 137 & 478 \\
\hline Georgia & 335557084312802 & rw204 & $33^{\circ} 55^{\prime} 57^{\prime \prime}$ & $84^{\circ} 31^{\prime} 29^{\prime \prime}$ & 1,072 & 200 & 28 & 200 \\
\hline Georgia & 335605084312101 & Sct4 & $33^{\circ} 56^{\prime} 57^{\prime \prime}$ & $84^{\circ} 31^{\prime} 20^{\prime \prime}$ & 1,009 & 600 & 83 & 600 \\
\hline Georgia & 335612084312901 & Sct6 & $33^{\circ} 56^{\prime} 13^{\prime \prime}$ & $84^{\circ} 31^{\prime} 31^{\prime \prime}$ & 1,025 & 575 & 57 & 575 \\
\hline Louisiana & -- & Lake Felicity & $29^{\circ} 20^{\prime} 59^{\prime \prime}$ & $90^{\circ} 24^{\prime} 48^{\prime \prime}$ & 0 & - & - & - \\
\hline Louisiana & -- & Oyster Bayou & $29^{\circ} 15^{\prime} 42^{\prime \prime}$ & $91^{\circ} 05^{\prime} 42^{\prime \prime}$ & 0 & - & - & - \\
\hline Lousiana & -- & Bay Junop & $29^{\circ} 12^{\prime} 16^{\prime \prime}$ & $91^{\circ} 03^{\prime} 56^{\prime \prime}$ & 0 & - & - & - \\
\hline Louisiana & 07381328 & $\begin{array}{c}\text { Houma Navigation } \\
\text { Canal at Dulac }\end{array}$ & $29^{\circ} 23^{\prime} 06^{\prime \prime}$ & $90^{\circ} 43^{\prime} 47^{\prime \prime}$ & 0 & - & - & - \\
\hline Nevada & 363213116133800 & TR-3 & $36^{\circ} 32^{\prime} 13^{\prime \prime}$ & $116^{\circ} 13^{\prime} 38^{\prime \prime}$ & 2,402 & 807 & 620 & 678 \\
\hline Nevada & 363905116005801 & SM-23-1 & $36^{\circ} 39^{\prime} 05^{\prime \prime}$ & $116^{\circ} 00^{\prime} 58^{\prime \prime}$ & 3,543 & 1,338 & 1,302 & 1,332 \\
\hline
\end{tabular}

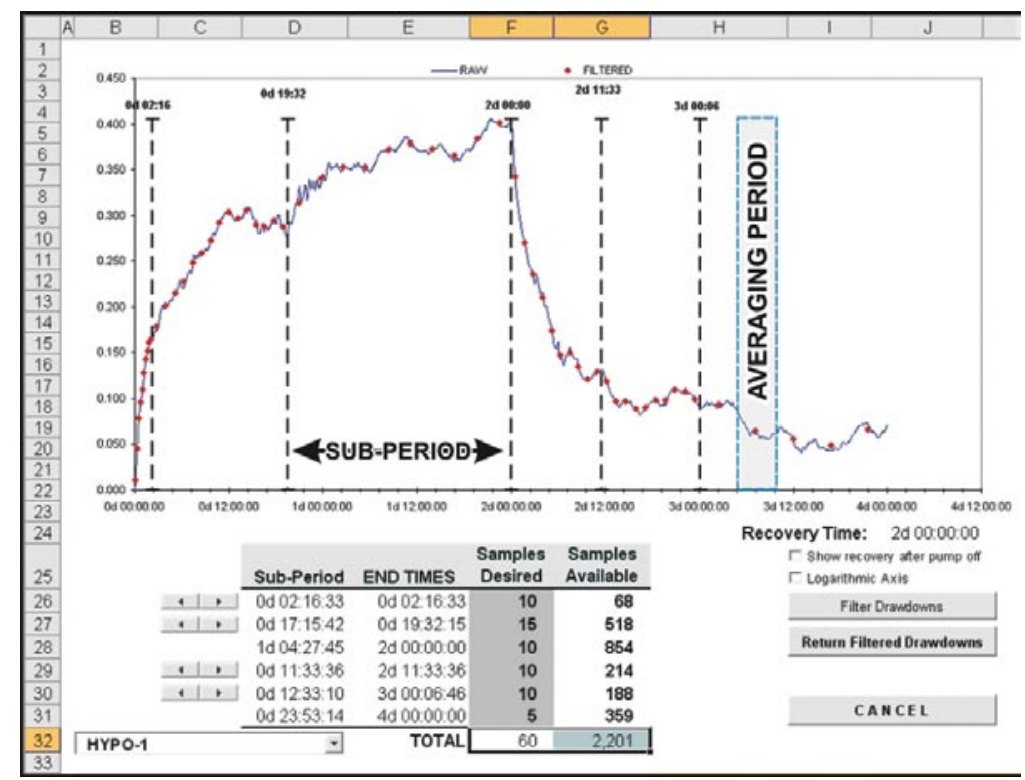

Figure 6. Example of drawdown filter, sub-periods, and averaging periods. 

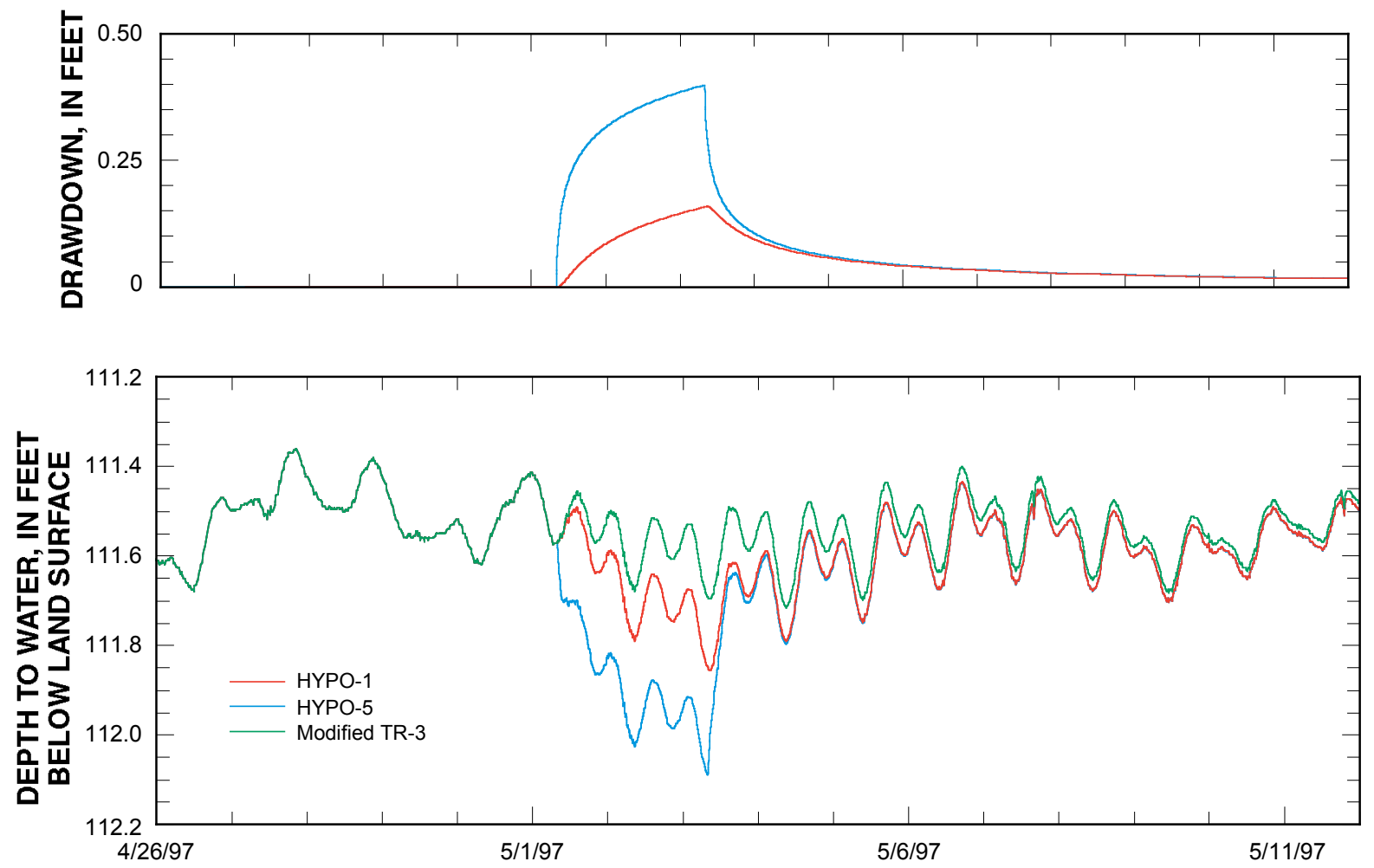

Figure 7. Water levels in wells HYPO-1, HYPO-5, and modified TR-3 and drawdowns in wells HYPO-1 and HYPO-5, April 26 to May 11, 1997.

Hypothetical water-level series HYPO-1 and HYPO-5 were created with the Theis model at radial distances of 1,000 and 5,000 ft, respectively, from the pumping well (fig 7). Unpumped water levels in wells HYPO-1 and HYPO-5 were the measured water levels from well TR-3 after multiplying by 1.4 , adding $53.2 \mathrm{ft}$, and shifting forward 75 minutes. Pumping affected water levels were created at 2-minute intervals during the first 50 hours of the test and at 4-minute intervals during the remainder of the recovery period. Synthetic water levels that use well TR-3 will perfectly match measured water levels in either HYPO-1 or HYPO-5 because TR-3 is the underlying series in these hypothetical records.

Drawdown and recovery in well HYPO-5 were estimated between 5/1/1997 8:00 and 5/5/1997 8:00 (fig. 8). Synthetic water levels were created for HYPO-5 with barometric changes, dry earth tide, and water levels in well SM-23-1. The synthetic water levels matched measured water levels with a RMS error of $0.01 \mathrm{ft}$ during the 2-week fitting period prior to the aquifer test. Drawdown and recovery were observed easily in the estimated time-series for HYPO-1, which was within $0.01 \mathrm{ft}$ of the original Theis solution on average.

Eliminating more than 97 percent of the observations by averaging did not alter the interpretation or statistics of the estimated drawdown series (fig. 8). The raw drawdown series for HYPO-5 contained 2,203 observations during the 4-day period of analysis, which was reduced to 65 observations in the filtered drawdown series. Minimum, maximum, average, and standard deviation of the differences between a drawdown series and the original Theis solution were $-0.05,0.02,-0.01$, and $0.01 \mathrm{ft}$, respectively, for both raw and filtered drawdowns.

The fitting and drawdown estimation processes would be repeated for HYPO-1 and any other observation well because the fitting coefficients differ between synthetic water-level series. Amplitude multipliers, phase shifts, and offsets are the fitting coefficients that are estimated for each synthetic water-level series. These fitting coefficients differ between water-level series to approximate each unique water-level series and should be unique even if the underlying time-series components are the same.

\section{Drawdown Detection Limits}

Drawdown detection limits affect hydraulic property estimates from aquifer tests. Hydraulic properties such as specific yield cannot be estimated when drawdowns are not detected in distant observation wells. The observations are still useful because a minimum specific yield can be determined by fitting a ground-water flow solution to the minimum detectable drawdown. Likewise, a maximum vertical hydraulic conductivity for a confining unit also can be determined. A drawdown detection limit typically is related to drawdown prediction error which is unknown during an aquifer test.

Prediction errors were computed and compared to fitting errors where local pumping was absent. RMS errors during 

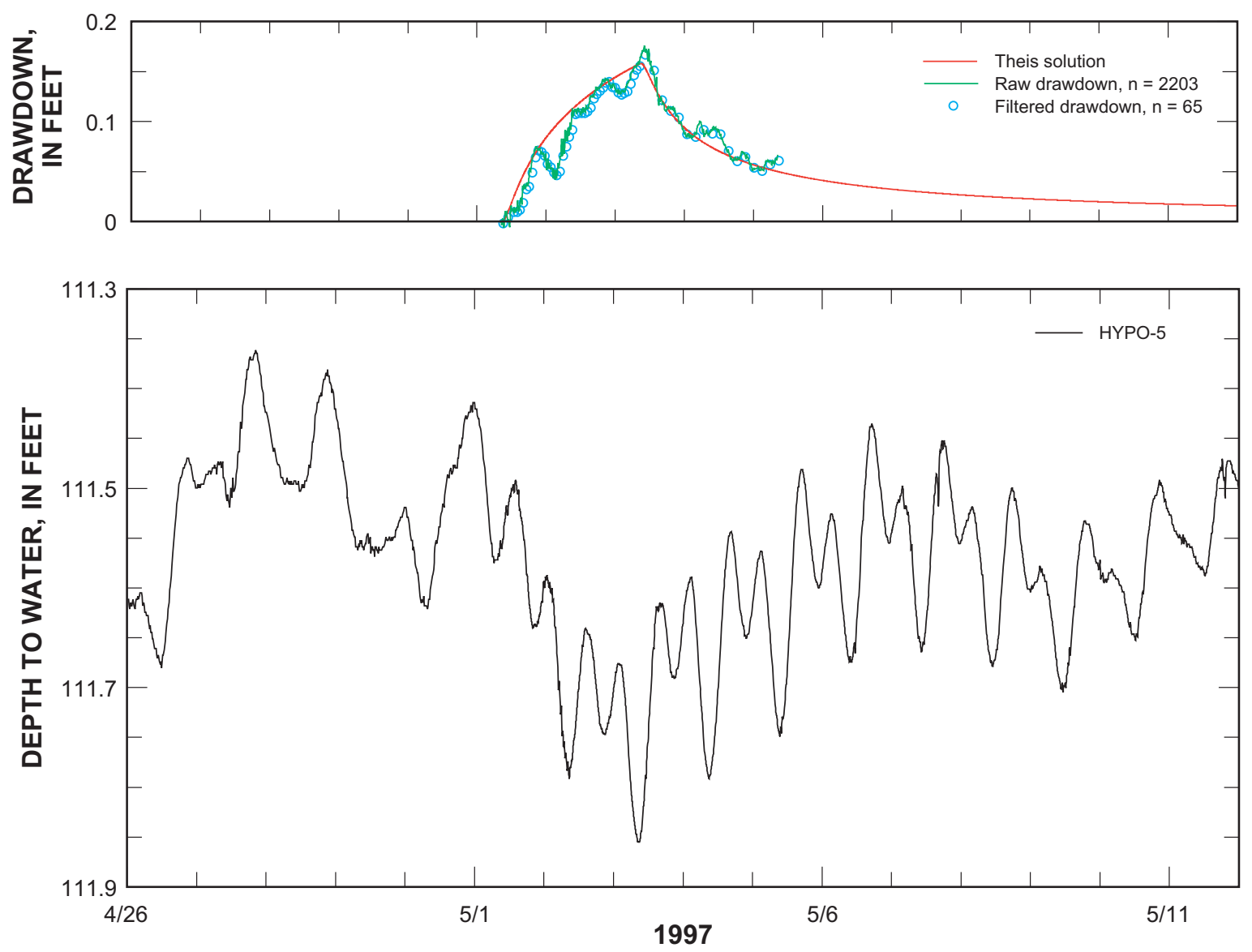

Figure 8. Water levels in well HYPO-5 and Theis, raw, and filtered drawdowns, April 26 to May 11, 1997.

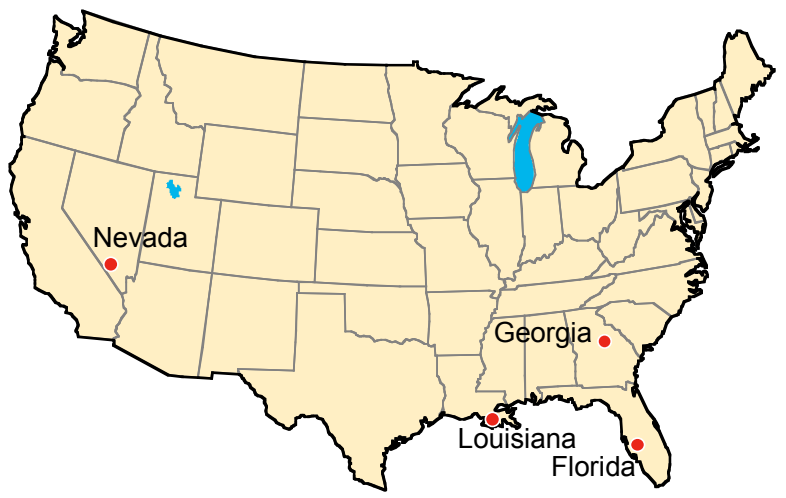

Figure 9. Fitting and prediction error comparison sites. fitting and prediction periods were compared at four geographically diverse sites in Florida, Georgia, Louisiana, and Nevada (fig. 9). Multiple synthetic water levels were created in a well at each site with fitting periods of $3,7,14,28$, and 56 days. RMS errors during fitting periods were compared to RMS errors during 7-day prediction periods. Two prediction periods were investigated at each site for eight prediction periods in total.

Synthetic water levels were created with six or more time-series components at each of the four sites (fig. 10). Many components created many degrees of freedom, which allowed for a better match to measured water levels. Several of the components likely were extraneous, but did not compromise the synthetic water-level results. For example, synthetic water levels were fit to measured water levels in well SM-23-1 between 4/17/1997 and 5/1/1997. RMS error was $0.0078 \mathrm{ft}$ using barometer, earth tide, gravity tide, and background well TR-3 as synthetic water-level components. RMS error was reduced to $0.0071 \mathrm{ft}$ by adding two components, a 24-hour moving average of water levels in well TR-3 and differences between water levels in well TR-3 and the moving averages. Results were functionally unchanged and the predictive power of the synthetic water levels was not degraded. 


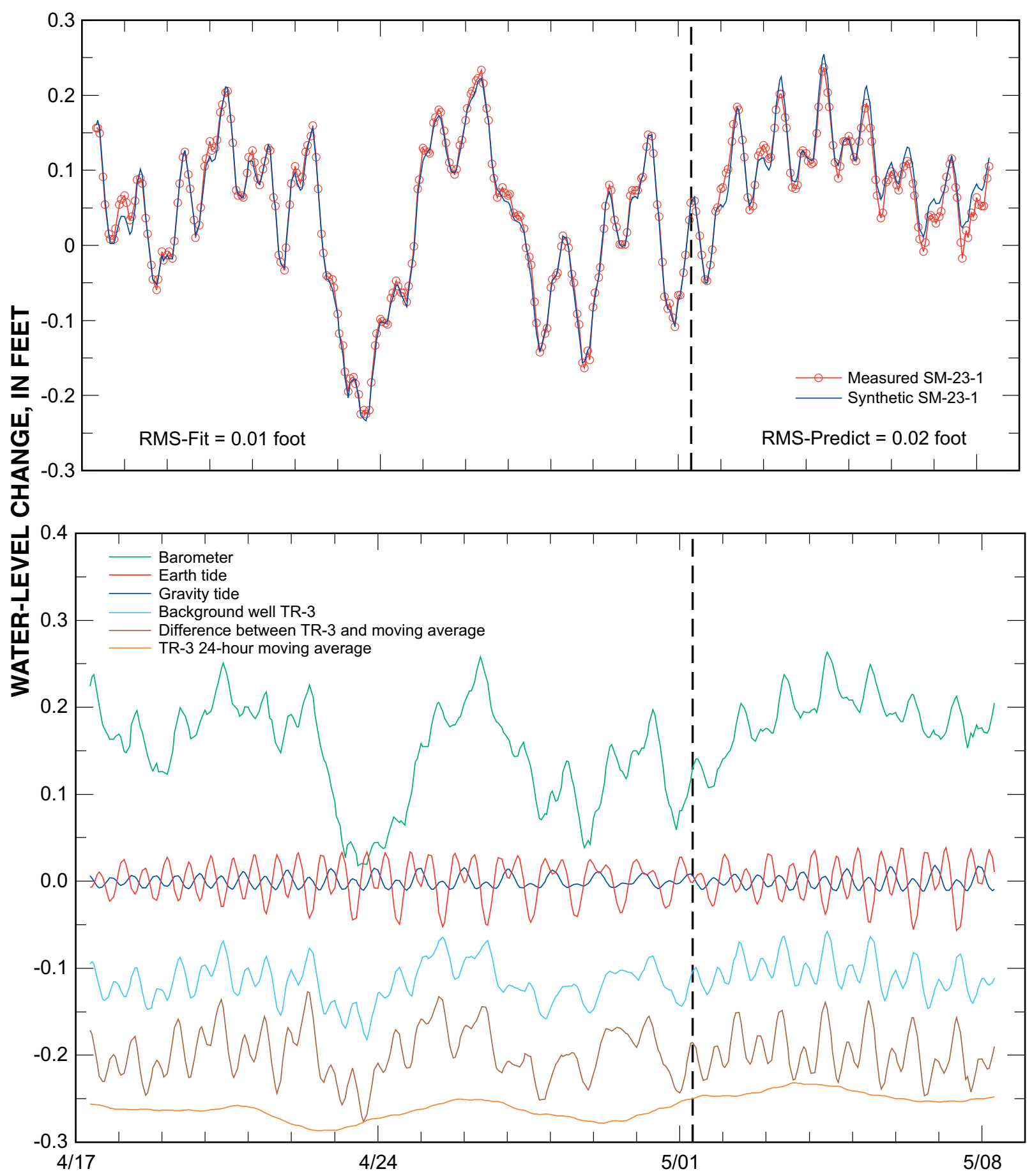

Figure 10. Measured water levels, synthetic water levels, and water-level components in well SM-23-1, Nevada, during a 14-day fitting period and a 7-day prediction period that began May 1, 1997. 


\section{Documentation of a Spreadsheet for Time-Series Analysis and Drawdown Estimation}

Prediction error was assumed to be related to fitting error by a simple multiplier (table 2). Ratios of prediction-to-fitting error decreased to nearly 1 with fitting periods of more than two times the prediction periods. Large ratios of predictionto-fitting error occurred when fitting periods were less than or equal to prediction periods. These large ratios resulted from small fitting errors and large prediction errors (fig. 11).

Water-level predictions from shorter fitting periods frequently were biased because a longer-term trend was not reproduced by the synthetic water levels (fig. 12). Synthetic and measured water levels differed by their respective RMS errors at the end of the prediction periods at the sites in Florida (fig. 12), Georgia (fig. 12), and Nevada (fig. 10). The magnitude of the errors ranged from 5 to 20 percent of the predicted change in water levels. The greatest relative error occurred at the Georgia site where the predicted change in water levels was only $0.2 \mathrm{ft}$.

Table 2. Ratios of prediction-to-fitting errors, prediction periods, water-level ranges, and prediction-error ranges at sites in Florida, Georgia, Louisiana, and Nevada

\begin{tabular}{|c|c|c|c|c|c|c|c|c|c|}
\hline \multirow{3}{*}{ Site } & \multicolumn{5}{|c|}{ Prediction error divided by fitting error } & \multirow{3}{*}{$\begin{array}{l}\text { Start of 7-day } \\
\text { prediction } \\
\text { range }\end{array}$} & \multirow{3}{*}{$\begin{array}{c}\text { Water-level } \\
\text { range, } \\
\text { in feet }\end{array}$} & \multirow{2}{*}{\multicolumn{2}{|c|}{ Prediction error, in feet }} \\
\hline & \multicolumn{5}{|c|}{ Fitting period } & & & & \\
\hline & 3-day & 7-day & 14-day & 28-day & 56-day & & & Minimum & Maximum \\
\hline Florida & 9.2 & 4.9 & 3.7 & 1.6 & 1.0 & $08 / 12 / 2004$ & 1.86 & 0.08 & 0.16 \\
\hline Florida & 56.8 & 4.5 & 1.7 & 1.0 & 1.1 & $11 / 12 / 2004$ & 2.30 & .28 & .92 \\
\hline Georgia & 11.3 & 6.5 & 1.8 & .8 & .4 & $04 / 24 / 2004$ & .21 & .01 & .03 \\
\hline Georgia & 26.8 & 4.9 & 1.5 & 1.1 & .9 & $05 / 17 / 2004$ & .30 & .02 & .08 \\
\hline Louisiana & 5.4 & 2.2 & 1.9 & 1.6 & 1.3 & $05 / 16 / 2002$ & 2.70 & .09 & .19 \\
\hline Louisiana & 5.6 & 1.5 & 1.2 & 1.0 & .9 & $06 / 02 / 2002$ & 1.10 & .05 & .12 \\
\hline Nevada & 2.5 & 3.9 & 1.9 & 1.0 & 1.0 & 05/10/1997 & .28 & .01 & .02 \\
\hline Nevada & 4.0 & 2.6 & 3.0 & .9 & .4 & 06/10/1997 & .53 & .01 & .02 \\
\hline
\end{tabular}



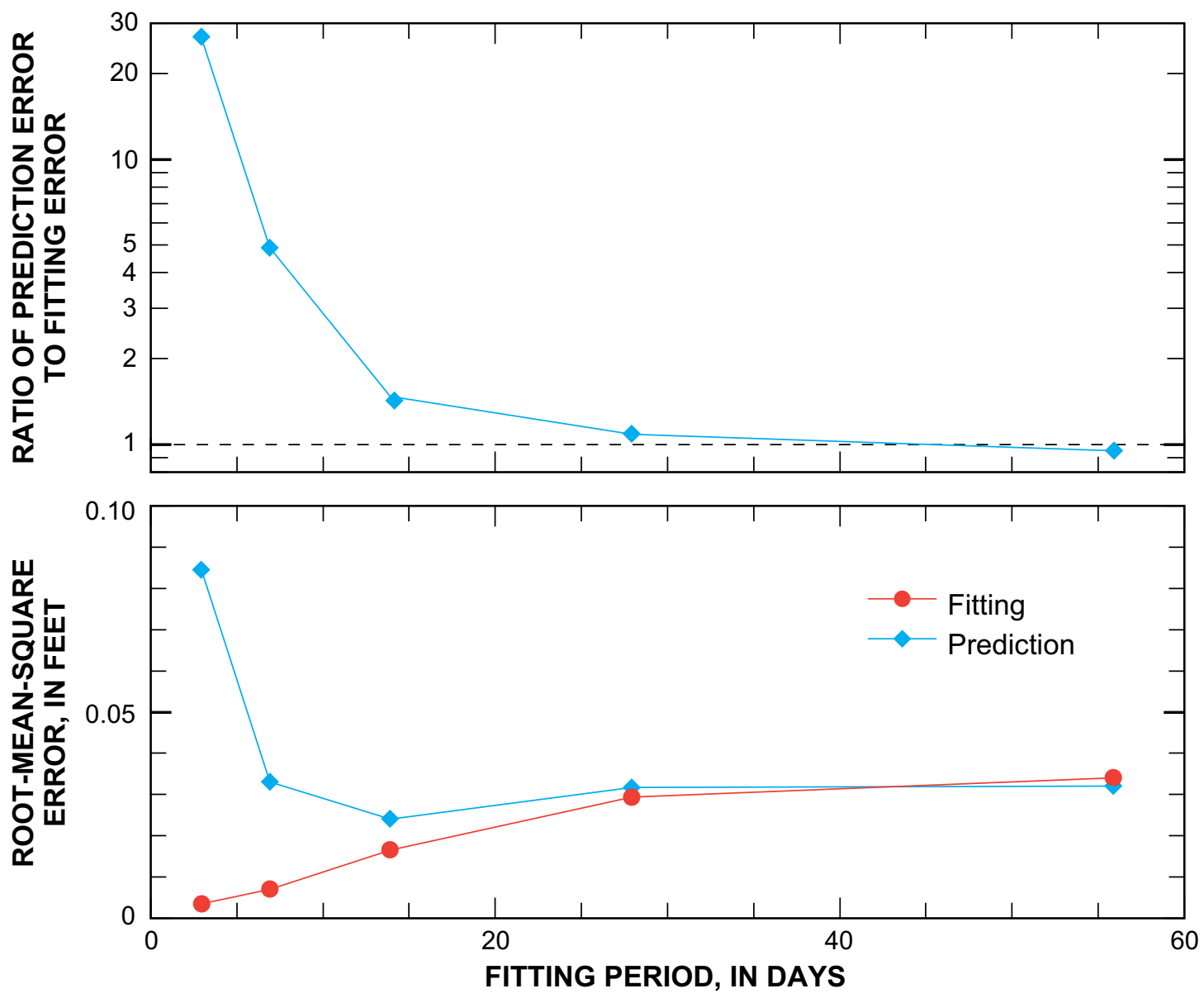

Figure 11. Fitting and prediction errors for five synthetic water levels in well sct4 in Georgia, with a 7-day prediction period that begins May 27, 2004. 

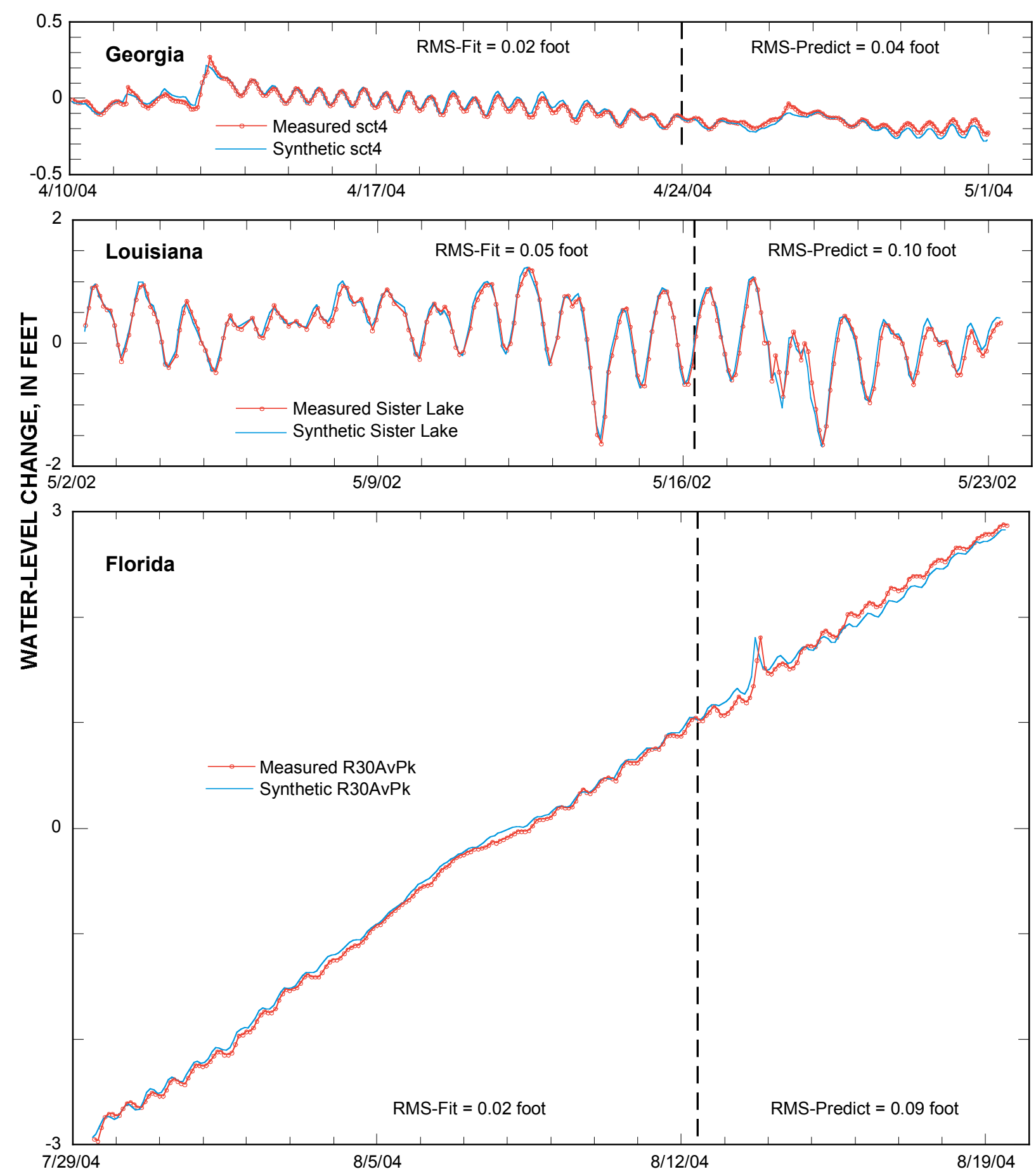

Figure 12. Measured and synthetic water levels at sites sct4 in Georgia, Sister Lake in Louisiana, and R30AvPk in Florida during 14-day fitting periods and 7-day prediction periods. 


\section{Instructions for Time-Series Analysis Workbook}

Time-series analysis, data filtering, synthetic water-level simulation, and drawdown estimation are performed within an Excel workbook, TimeSeries+Drawdown.RV1.0.xls. Workbook pages are revealed sequentially as needed to analyze time series. All four workbook pages remain visible after being used unless the "RESET ALL" button on the TimeSeries page is pressed. Pressing the "RESET ALL" button eliminates all user-defined data, removes all series from charts, and hides all worksheets but the TimeSeries page.

The Time-Series Analysis workbook relies on inherent features of Excel 9.0+ and user-defined macros. The macro security

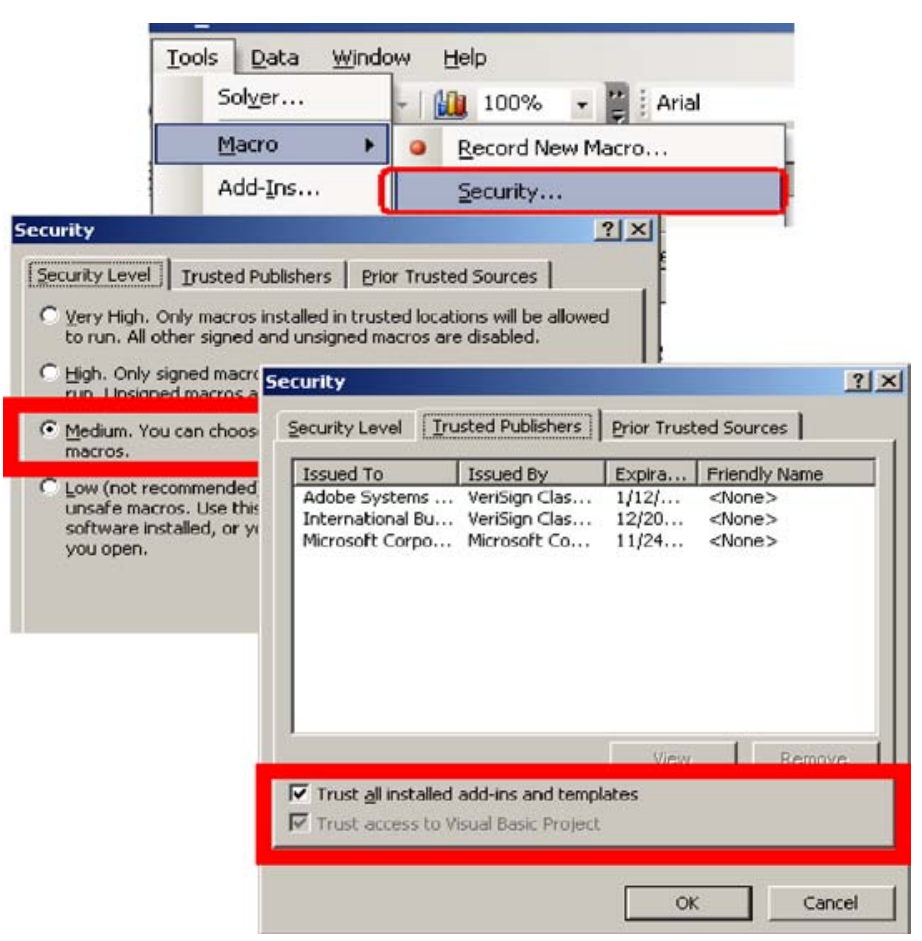

Figure 13. Example of Excel forms for changing security settings. level should be set to Medium (fig. 13) because the program will not function if the macro security level is set to $\underline{\text { High }}$ or Very high. The program will work with a macro security level of Low but this is ill advised. All macros, including malicious viruses, are activated without warning upon opening Excel. This program also needs access to VBA and the "Trust all installed add-ins and templates" option must be checked (fig. 13).

The Time-Series Analysis workbook fits synthetic water levels to measured water levels with the SOLVER add-in. The SOLVER is a general optimization routine that adjusts cell values to meet a user-specified objective. Adjusted cell values, parameters, can be constrained to userdefined ranges. Sum-of-squares differences are minimized in the Time-Series Analysis workbook. The SOLVER addin is distributed with Excel and users must have this add-in installed. The path to the SOLVER library changes between versions of Excel; therefore, references to the SOLVER library are specified dynamically and trusted access to VBA is needed.

Input and heading cells have been identified with consistent formatting. Input cells are formatted with a pale yellow background and bounded by double lines. Data should be entered by either typing directly or pasting special as values. Help for data input is provided by the comments that are tagged in the associated heading cell.

Cell Formatting in the Time-Series Analysis Workbook

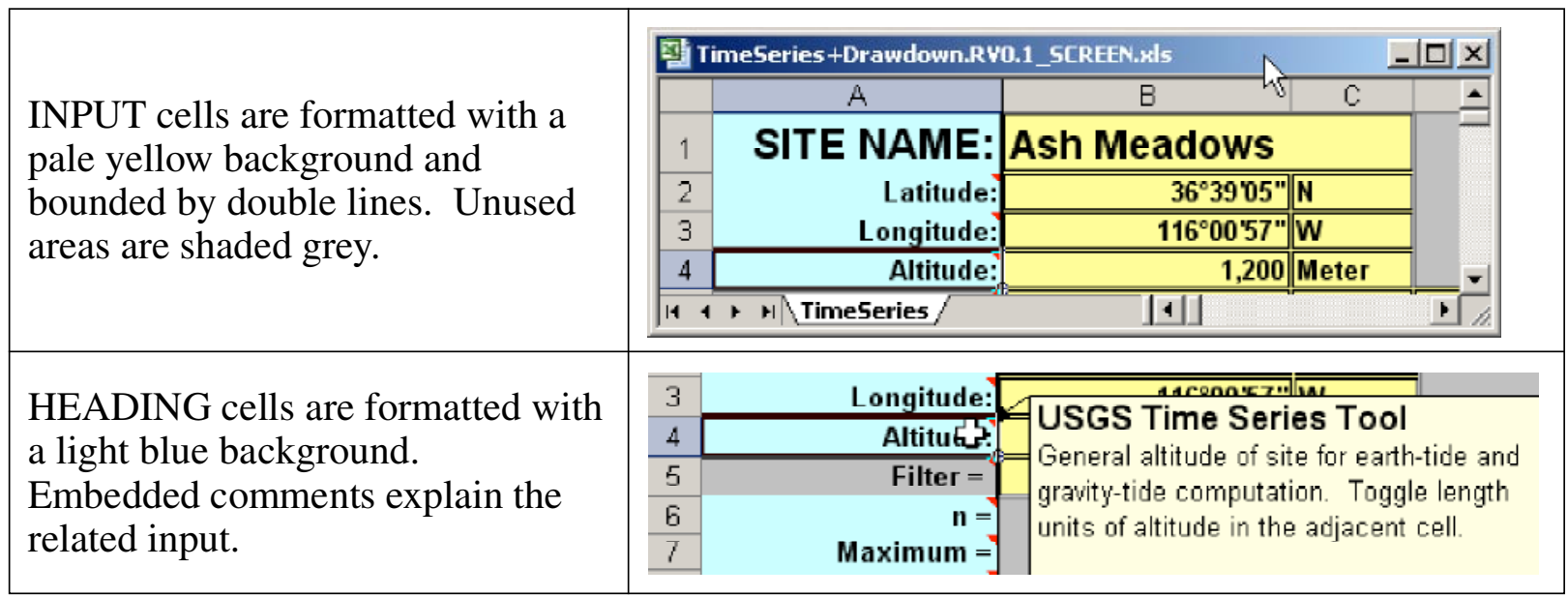




\section{Step-by-Step Instructions}

Step-by-step instructions for the TimeSeries+Drawdown spreadsheet also are provided in the appendix. The step-by-step instructions explicitly track each operation used to analyze the Nevada example. Users are referred specifically to a workbook, page, and cell for each operation. Limited descriptions of the actions are reported.

\section{TimeSeries Page}

All data are entered and stored on the TimeSeries page. Time-series are entered with multiple responses for a given time (fig. 14, columns B:D) or as independent time-response pairs. Columns of time entries are differentiated from columns of measured responses by the "DATE-TIME" label in row 12. Site name and location specified on the TimeSeries page. Latitude, longitude, and altitude are needed to compute the areal strain and gravity tides (Harrison, 1971).

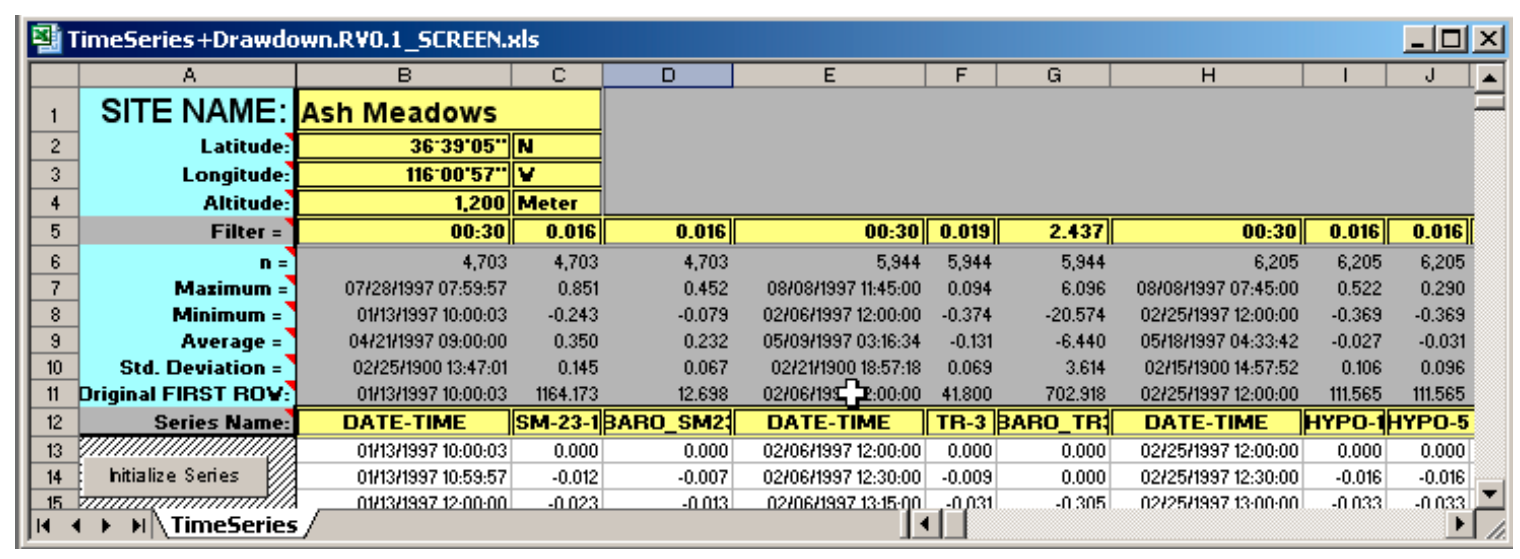

Figure 14. Example of TimeSeries page with data entered.

Pasting Data into the Time-Series Analysis Workbook

Analysis workbook is distributed with no data and only the

TimeSeries page visible. Arrange input series in a data-source workbook as contiguous blocks of time and water level.

$N V_{-}$WLsource.xls is the data-source workbook that is distributed as an example.

Copy data from the data-source workbook and Paste Special... to the analysis workbook.

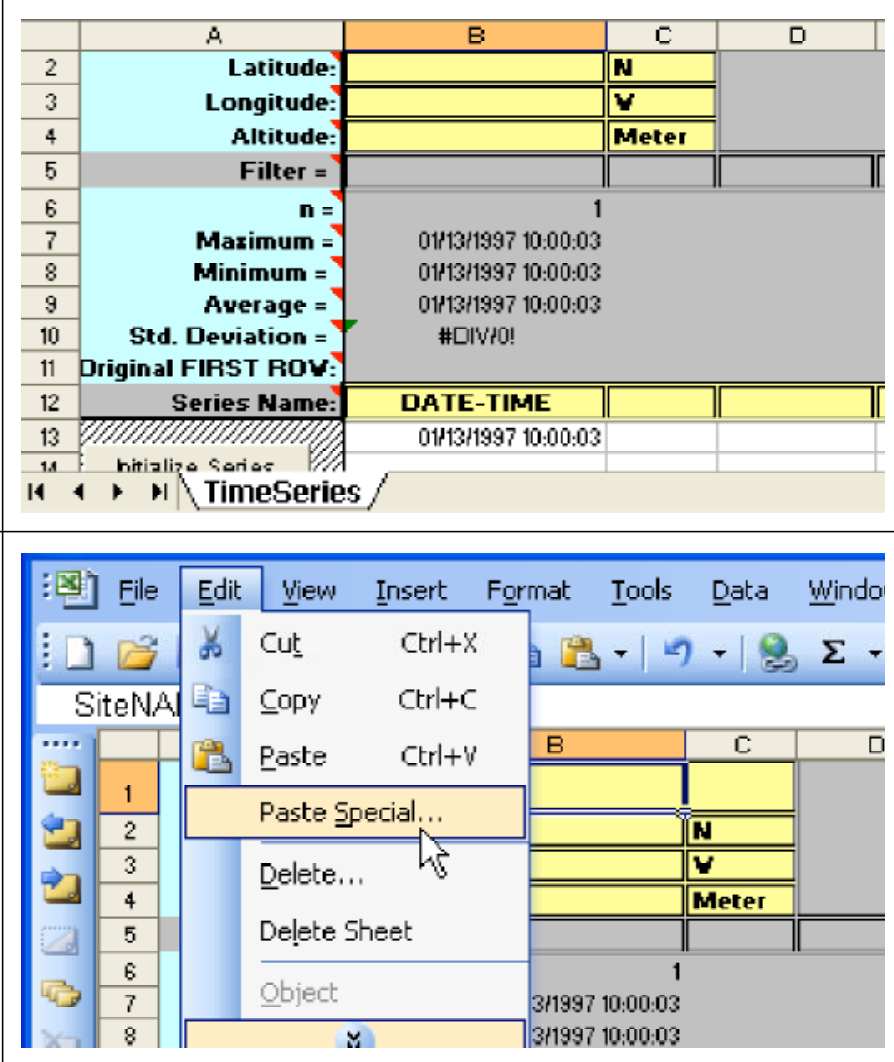


Paste Special as values to preserve formatting in the analysis workbook and break links to the data-source workbook.
Use the pulldowns in cells $\mathrm{C} 2: \mathrm{C} 3$ to designate the correct hemispheres for latitude and longitude. Assign the correct altitude units in cell $\mathrm{C} 4$.

Copy the large data block from the data-source workbook by Selecting the upper-left cell, Holding the SHIFT key \& Pressing $<$ ctrl $>+<$ end $>$. Copy region into memory.

Activate the analysis workbook. Paste Special as Values to cell B12.

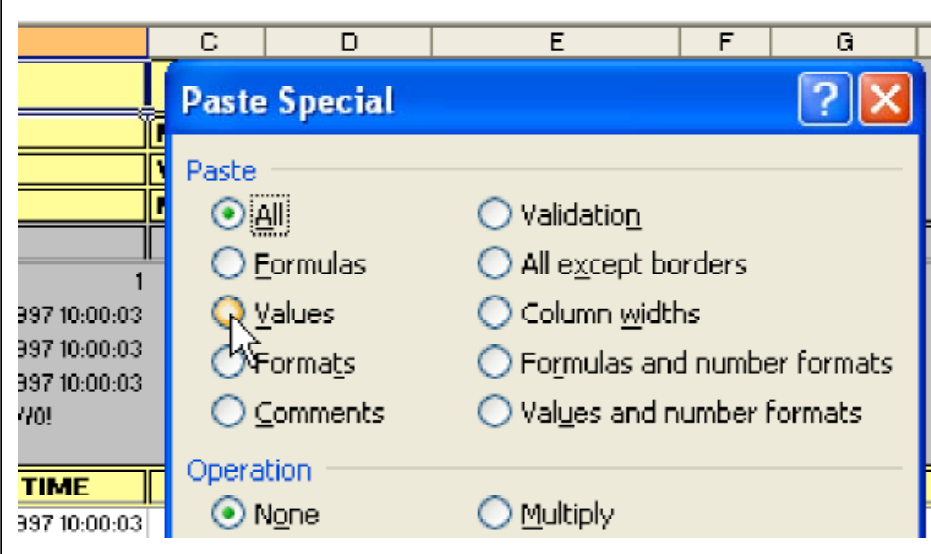

A

SITE NAME: Ash Meadows

Latitude: $36^{\circ} 39^{\circ} 05^{\prime \prime}$

Longitude: $\quad 116^{\circ} 00 \mathrm{~N}$ Altitude: 1, ZOU IIIETा Filter $=$

$\mathbf{n}=$

Maximum $=\quad$ 01/13/1997 10:00:03

Minimum $=\quad$ 01/13/1997 10:00:03

Average $=\quad 01 / 13 / 199710: 00: 03$

Sta nousation - F thisen।

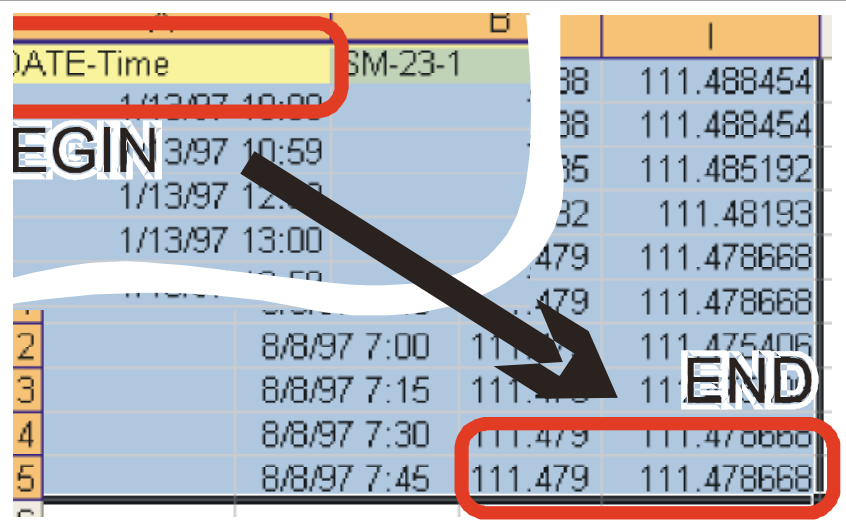

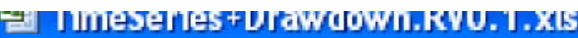

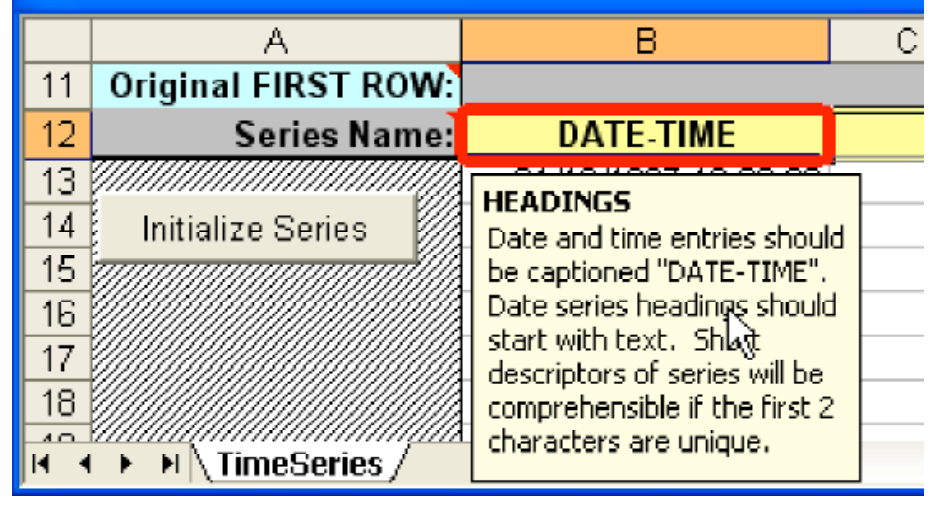

Date and time entries should be captioned "DATE-TIME". Date series headings should start with text. Short descriptors of timeseries components will be comprehensible if the first 2 characters are unique. 
Time series can be filtered to reduce dataset size by eliminating less significant data points. A measured response is judged necessary if the response changes more than a user-specified amount since the last stored response. Small changes are defined by the smallest non-zero change in each data series to avoid specifying units. A user-specified maximum time between measurements also constrains the amount of data to be eliminated. These specifications are defined through Filter-Explanation-\&-Query wizard.

Initializing and Filtering Time Series

\begin{tabular}{|c|c|c|c|c|}
\hline \multirow{11}{*}{$\begin{array}{l}\text { Press the "Initialize Series" button } \\
\text { after inserting data. }\end{array}$} & \begin{tabular}{r|r}
8 & $\begin{array}{r}\text { Minimum } \\
\text { Aver age }\end{array}=$ \\
9 & $=$ \\
Std. Deviation & $=$ \\
11 & Driginal FIRST ROY
\end{tabular} & $\begin{array}{r}0113+1997 \text { 10:00:03 } \\
04 / 21+199709: 00: 00 \\
02 / 25+190013: 47: 01\end{array}$ & \multirow[b]{2}{*}{ SM-23-1 } & \multirow[b]{2}{*}{ 唒ARO_SM2: } \\
\hline & 12 Series Name: & DATE-time & & \\
\hline & 13 & $0113+1997$ 10:00:03 & 1164.173 & 12.698 \\
\hline & hitialize Serie & $01113+1997$ 10:59:57 & 1164.161 & 12.691 \\
\hline & 15 & 01+13/1997 12:00:00 & 1164.150 & 12.685 \\
\hline & 16 & $01+13 / 1997$ 13:00:03 & 1164.173 & 12.690 \\
\hline & 17 & $011319997359: 57$ & 1164.187 & 12.692 \\
\hline & 18 & $01+13+1997$ 15:00:00 & 1164.219 & 12.707 \\
\hline & 19 & $01+13+1997$ 16:00:03 & 1164.264 & 12.723 \\
\hline & 20 & $01113+1997$ 16:59:57 & 1164.287 & 12.731 \\
\hline & I 1 , TimeSerie & & & $<$ \\
\hline
\end{tabular}

\begin{tabular}{|c|c|c|c|c|c|}
\hline \multirow{7}{*}{$\begin{array}{l}\text { Row } 5 \text {, the filter row, will change } \\
\text { formatting from column B to the } \\
\text { right. }\end{array}$} & & A & $\mathrm{B}$ & $\mathrm{C}$ & D \\
\hline & 1 & SITE NAME: & \multicolumn{2}{|l|}{ Ash Meadows } & \\
\hline & 2 & & $\begin{array}{r}36^{\circ} 39^{\prime} 05^{\prime \prime} \\
\end{array}$ & $\mathbb{B}$ & \\
\hline & 3 & \multirow{3}{*}{$\begin{array}{l}\text { Longitude: } \\
\text { Altitude: } \\
\text { Filter }=\end{array}$} & $116^{\circ} 00^{\prime} 57^{\prime \prime}$ & W & \\
\hline & 4 & & 1,200 & \multicolumn{2}{|l|}{ Meter } \\
\hline & 5 & & 引 & & \\
\hline & 6 & \multirow{6}{*}{$\begin{array}{r}\mathbf{n}= \\
\text { Maximum }= \\
\text { Minimum }= \\
\text { Average }= \\
\text { Std. Deviation }= \\
\text { Original FIRST ROW: } \\
\text { Series Hame: }\end{array}$} & 1 & \\
\hline \multirow{5}{*}{$\begin{array}{l}\text { Cells will change from gray to light } \\
\text { yellow. }\end{array}$} & 7 & & \multirow{2}{*}{\multicolumn{3}{|c|}{$\begin{array}{l}\text { 01/3/1997 10:00:03 } \\
\text { 01/3/1997 10:00:03 }\end{array}$}} \\
\hline & 8 & & & & \\
\hline & 9 & & \multicolumn{3}{|l|}{ 01/13/1997 10:00:03 } \\
\hline & $\begin{array}{l}10 \\
11\end{array}$ & & \multicolumn{3}{|l|}{ \#DIV/0! } \\
\hline & 12 & & \multicolumn{3}{|l|}{ DATE-TIME } \\
\hline \multirow{6}{*}{$\begin{array}{l}\text { The Filter-Explanation-\&-Query } \\
\text { wizard will appear. Change filter } \\
\text { criteria in row } 5 \text { of the TimeSeries } \\
\text { worksheet. }\end{array}$} & & A & $\mathrm{B}$ & $\mathrm{C}$ & $\mathrm{D}$ \\
\hline & 1 & \multirow{4}{*}{$\begin{array}{r}\text { SITE NAME: } \\
\text { Latitude: } \\
\text { Longitude: } \\
\text { Altitude: }\end{array}$} & \multicolumn{2}{|l|}{ Ash Meadows } & \\
\hline & 2 & & \multicolumn{2}{|c|}{$36^{\circ} 39^{\prime} 05^{\prime \prime} \mid[$} & \\
\hline & 3 & & $116^{\circ} 00^{\prime} 57^{\prime \prime}$ & $\mathbf{W}$ & \\
\hline & 4 & & 1,200 & Meter & \\
\hline & 5 & Filter $=]$ & $00: 30$ & 00.002 & 0 \\
\hline \multirow{4}{*}{$\begin{array}{l}\text { If desired, reduce data set based on } \\
\text { time and measurement resolution. } \\
\text { Change all settings before pressing } \\
\text { the FILTER button. }\end{array}$} & 6 & & 4,703 & 4,703 & 4 \\
\hline & 7 & Maximum $=$ & 07/28/1997 07:59:57 & 1165.024 & 13 \\
\hline & $\begin{array}{l}8 \\
9\end{array}$ & $\begin{aligned} \text { Minimum } & = \\
\text { Average } & =\end{aligned}$ & \multicolumn{3}{|c|}{ FILTER EXPLANATION \& QUERY } \\
\hline & $\begin{array}{l}10 \\
11 \\
12\end{array}$ & $\begin{array}{r}\text { Std. Deviation }= \\
\text { Original FIRST ROW: } \\
\text { Series Name: }\end{array}$ & \multicolumn{3}{|c|}{$\begin{array}{l}\text { Reduce data set based on time an } \\
\text { in row } 5 \text {. Change settings before }\end{array}$} \\
\hline
\end{tabular}


Maximum time between filtered entries is assigned in DATE-TIME columns.
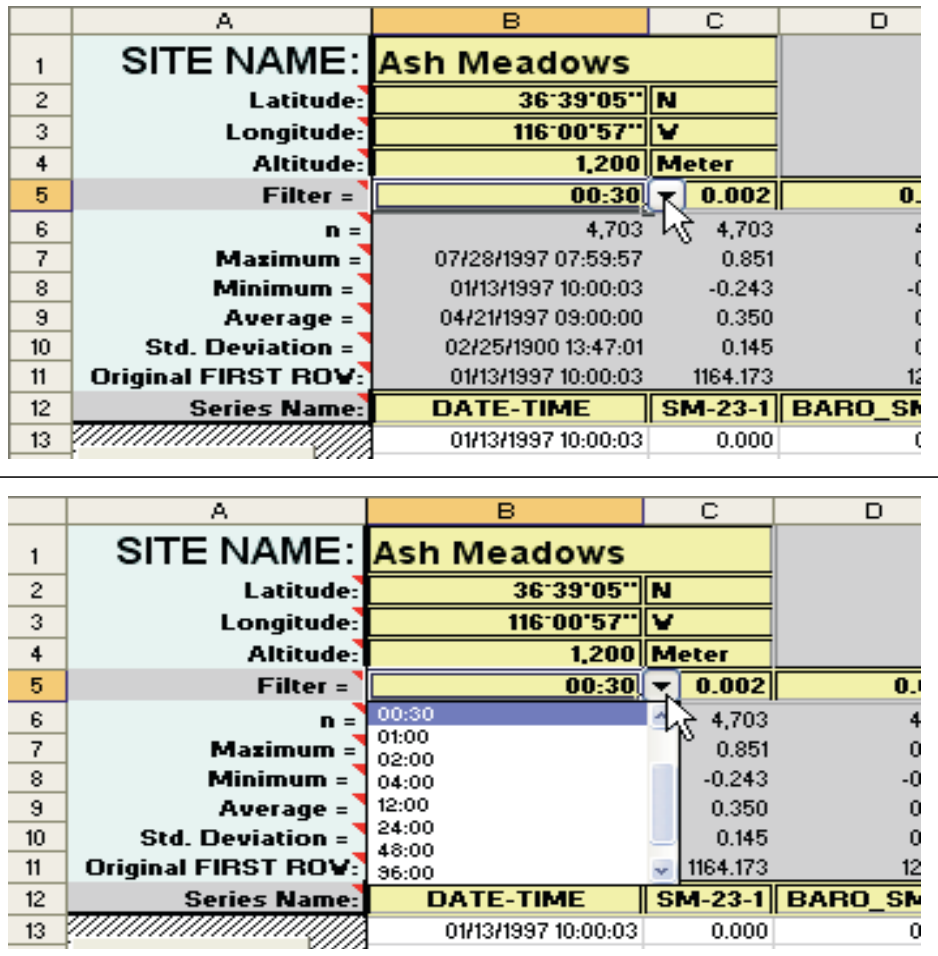

Data changes less than the filter value are considered insignificant and will be eliminated if the time between entries is less than the maximum time that was specified in the DATE-TIME column.

Choices are 1, 2, 4, 8, and 16 times the minimum, non-zero change between entries. filtering the data set.

\section{MAINTAIN BACK-UPS}

Raw data are eliminated permanently and replaced by filtered data!!!

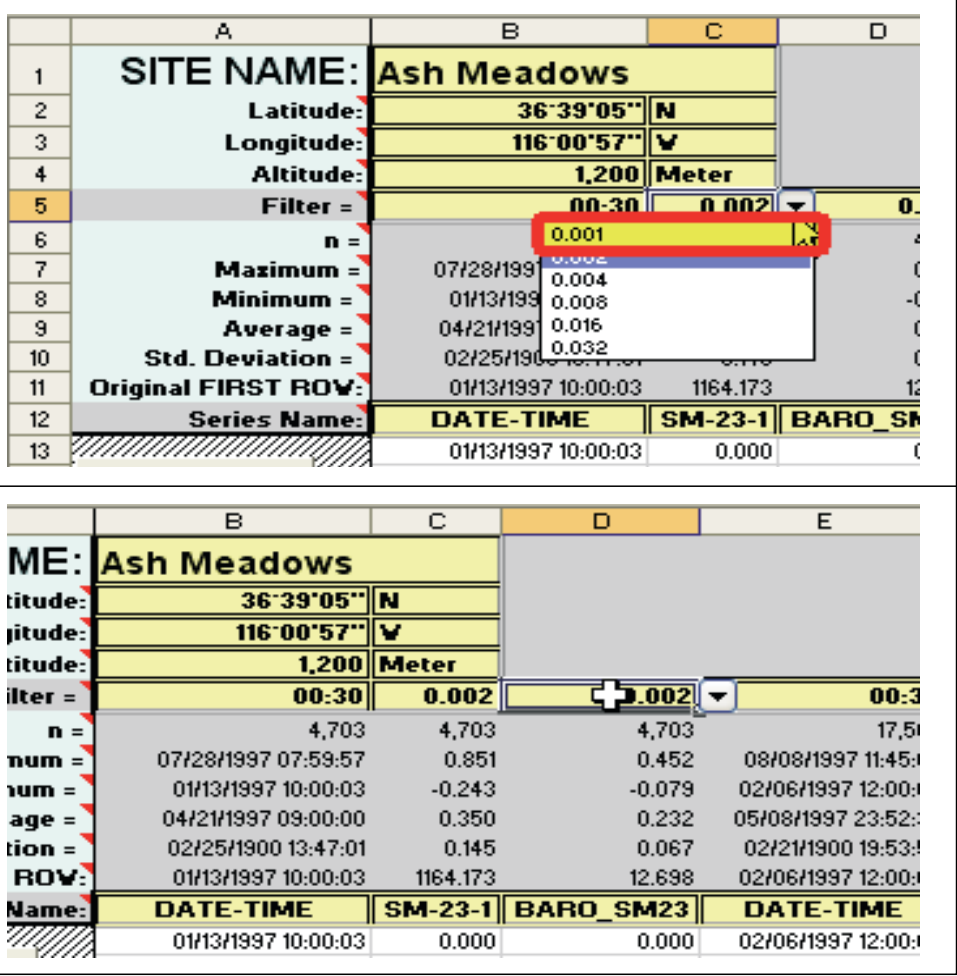




\begin{tabular}{|c|c|c|c|c|c|}
\hline \multirow{13}{*}{$\begin{array}{l}\text { Pressing the "Initialize Series" } \\
\text { button on the TimeSeries } \\
\text { worksheet also causes the SHOW } \\
\text { worksheet to be revealed. }\end{array}$} & $\begin{array}{l}3 \\
4\end{array}$ & $\begin{array}{r}\text { Longitude: } \\
\text { Altitude: }\end{array}$ & $\begin{array}{r}11600.57 \cdot- \\
1,200\end{array}$ & Meter & \\
\hline & 5 & Filter $=$ & 00:30 & 0.002 & trate \\
\hline & 6 & $\mathbf{n}=$ & 4,703 & 4,703 & \\
\hline & 7 & Maximum = & $07+28+199707: 59: 57$ & 0.851 & \\
\hline & 8 & Minimum = & $0113+1997$ 10:00:03 & -0.243 & \\
\hline & 9 & Average $=$ & 04/2111997 09:00:00 & 0.350 & \\
\hline & 10 & Std. Deviation = & $02+25 / 190013: 47: 01$ & 0.145 & \\
\hline & 11 & Driginal FIRST ROY: & $01113+1997$ 10:00:03 & 1164.173 & \\
\hline & 12 & Series Name: & DATE-TIHE & SH-23-1 & BARO_: \\
\hline & 13 & & $0113+1997$ 10:00:03 & 0.000 & \\
\hline & 14 & hitialize Series & $01113+199710: 59: 57$ & -0.012 & \\
\hline & 15 & WOWWUW & $0113+1997$ 12:00:00 & -0.023 & \\
\hline & 14 & 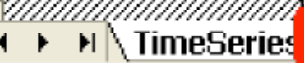 & HOW' $/$ & $|<|$ & \\
\hline
\end{tabular}

\section{SHOW Page}

Time-series data are viewed on the SHOW page, which was revealed after pressing the "Initialize Series" button on the TimeSeries page. Time-series data that could improve synthetic water-level simulation can be identified by inspecting hydrographs. Periods before an aquifer test are best for fitting synthetic water levels to measured water levels.

\section{Viewing Time Series}

Time series are viewed on the SHOW worksheet. Periods of record can be magnified. FITTING, ESTIMATION, and FEEL GOOD periods can be defined graphically.

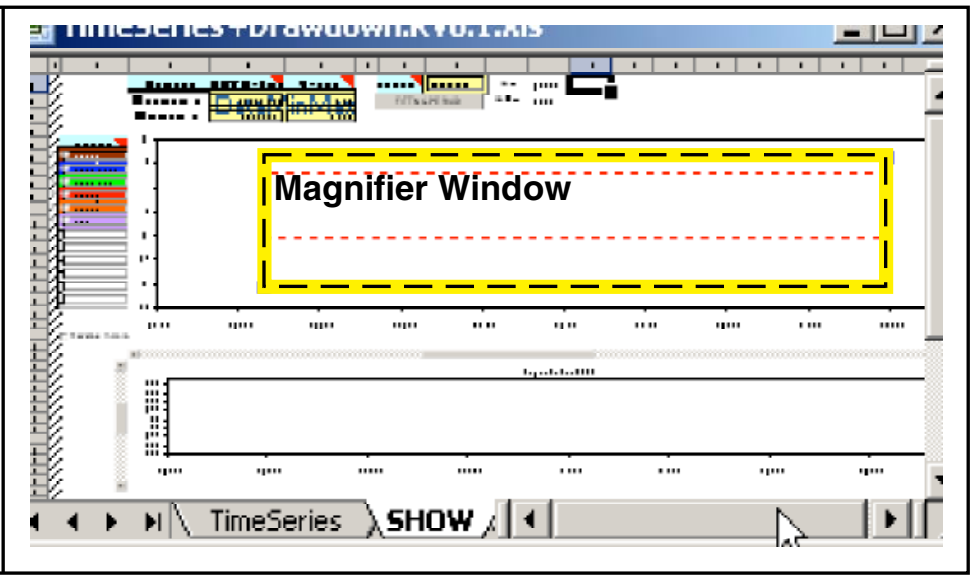


Check box in column B to display a time series.

Check box in column A to display on secondary axis.

Different series names can be selected from a pull-down menu in cells B6:B17.
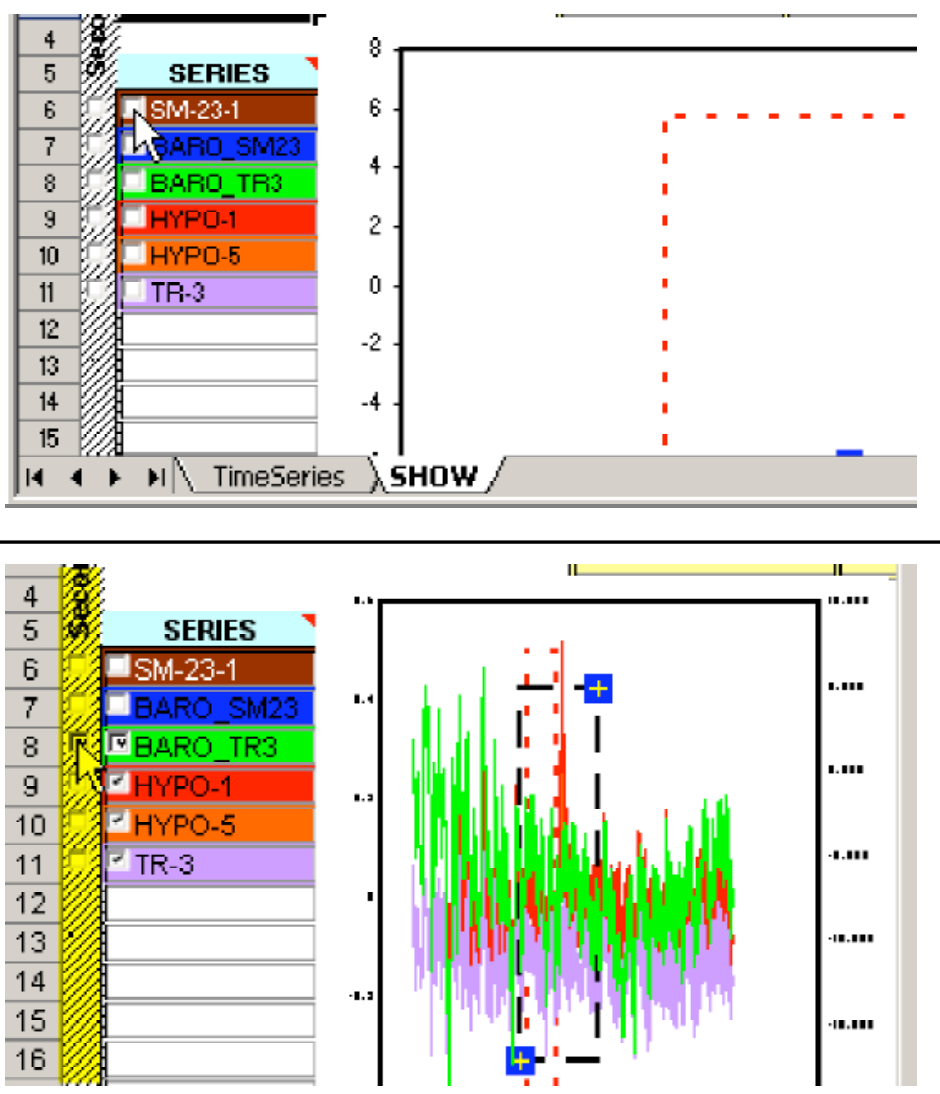

Different series names can be
selected from a pull-down menu in
cells B6:B17.
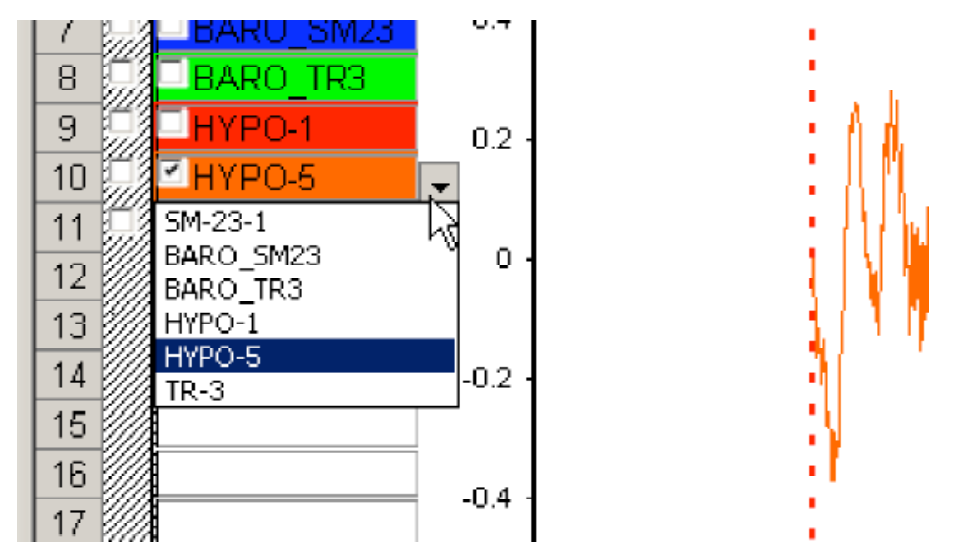


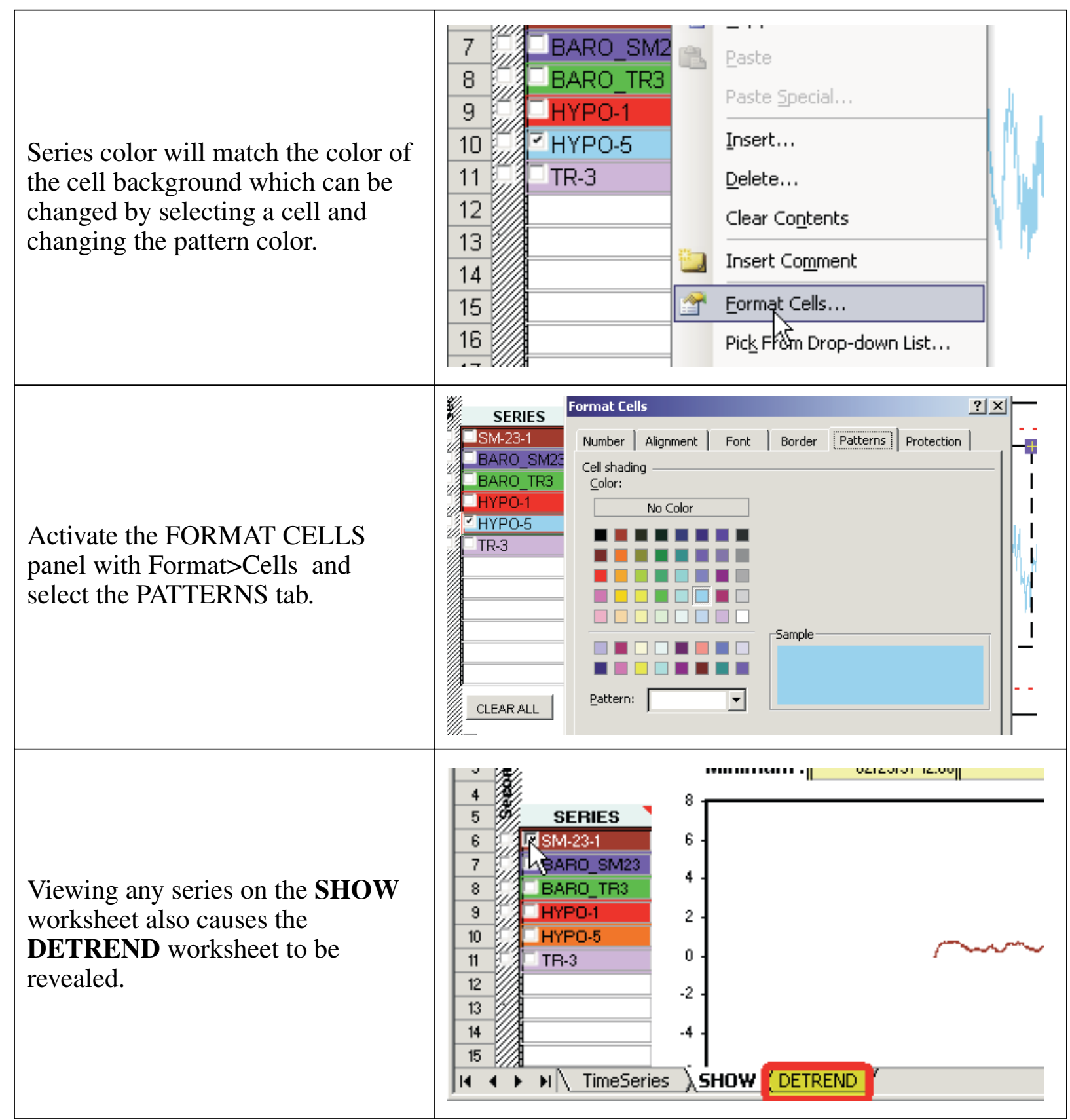

Time series are plotted on two charts so that selected records can be viewed at magnified scales. Height and width of magnifier window are adjusted graphically in the upper chart. Magnified area is viewed by sliding the vertical and horizontal scrollbars that bracket the lower window. Scrollbar sensitivity is controlled by minimum and maximum extents that are specified in cells D2:E3. 
Magnifying Selected Periods of Time Series

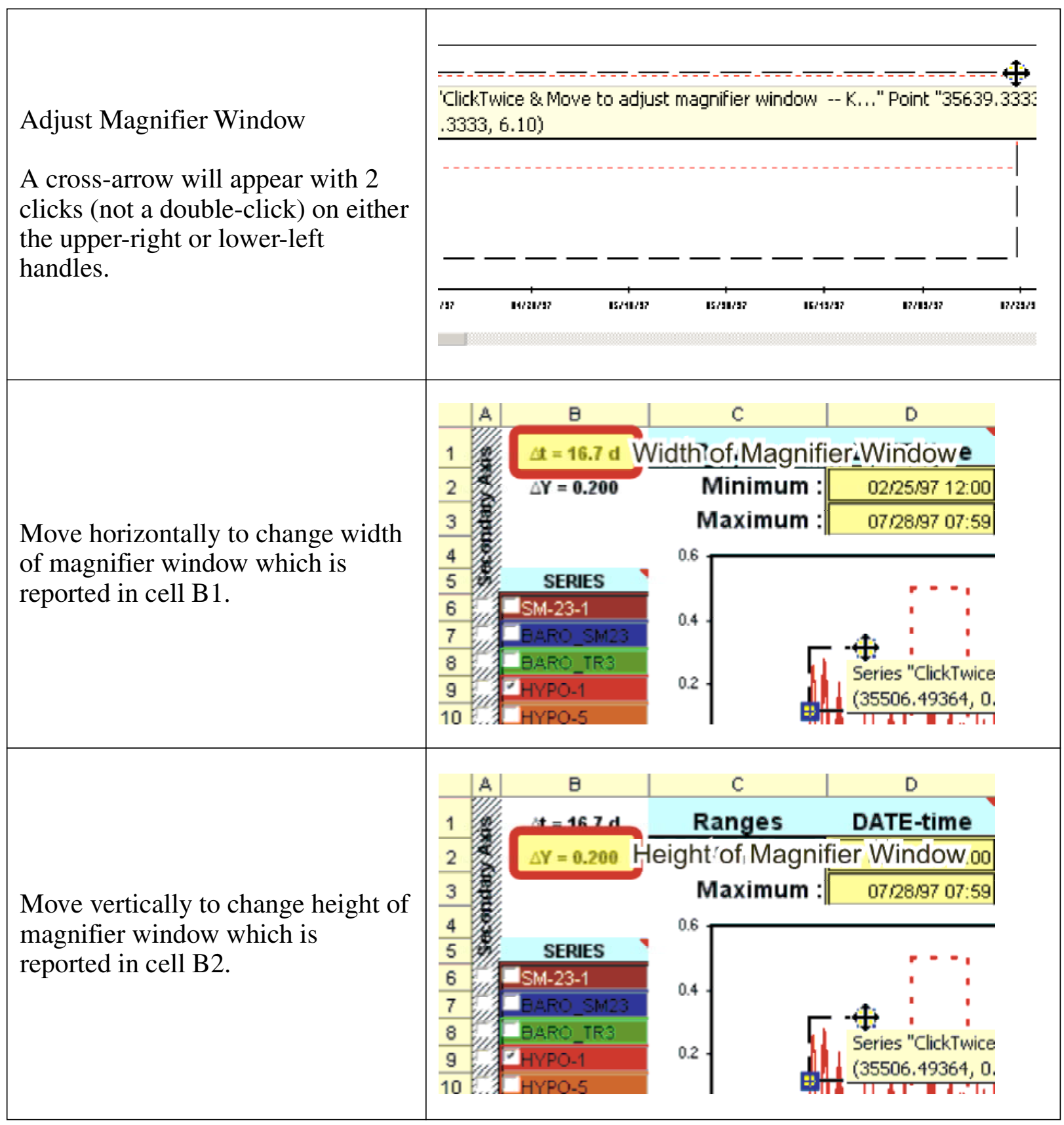


Minimum (E2) and maximum (E3) values define the limits of the vertical scrollbar. Range frequently is not initialized well when amplitudes of series differ greatly.

Enter reasonable minimum (E2) and maximum (E3) values of the Yaxis to reduce sensitivity of the vertical scrollbar.

Color of cells shifts from yellow to orange while scrollbar is selected.

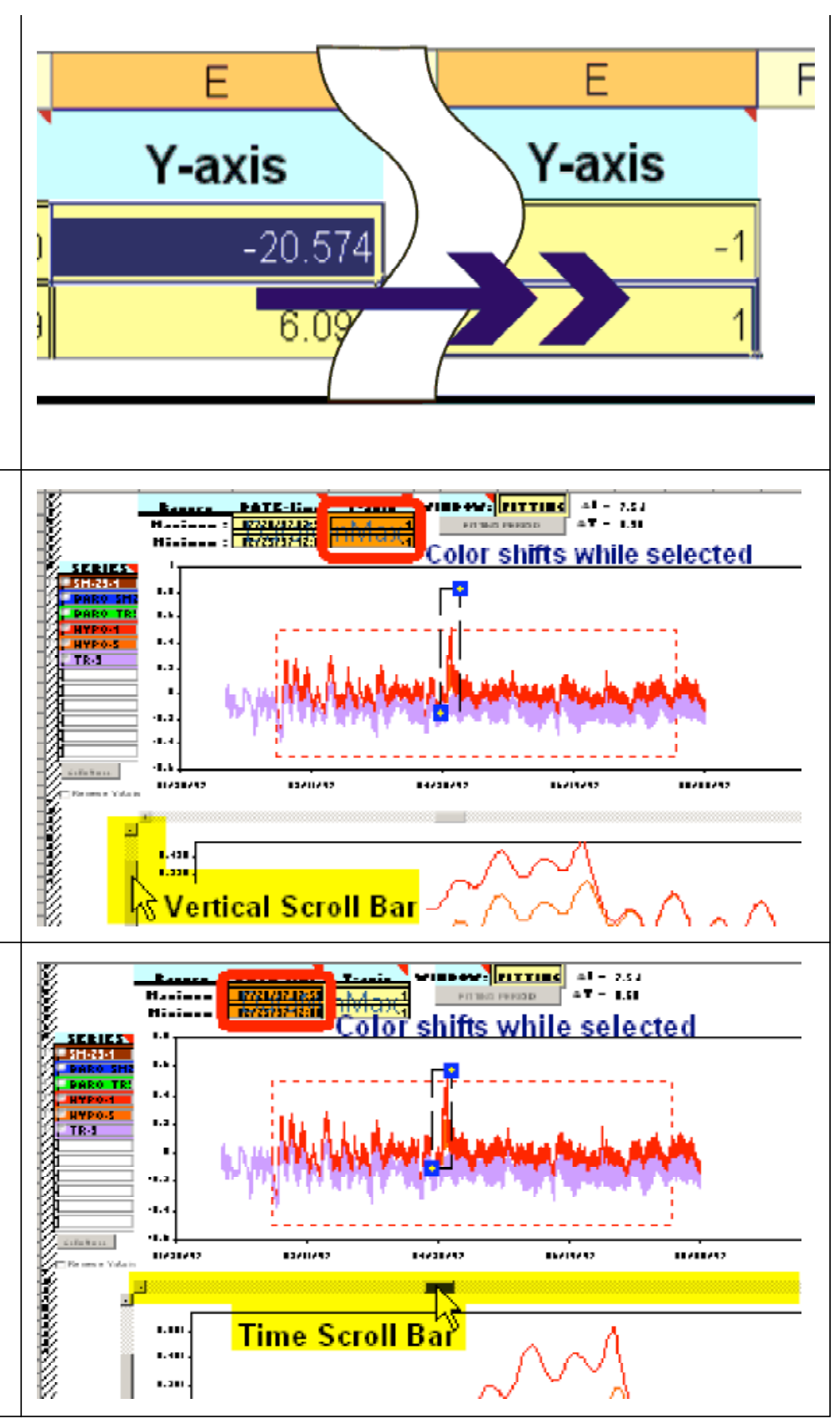

Fitting, estimation, and feel-good periods can be defined graphically from the SHOW page. Define the minimum and maximum times of a period with the magnifier window. Press the gray button in cell G2 to define the beginning and ending of a period. The fitting, estimation, and feel-good periods are defined in cells F27:F28, G27:G28, and H27:H28, respectively, on the DETREND page. Estimation periods for estimating drawdowns should be defined by typing directly into cells G27:G28 on the DETREND page. 
Graphically Defining Fitting, Estimation, and Feel-Good Periods

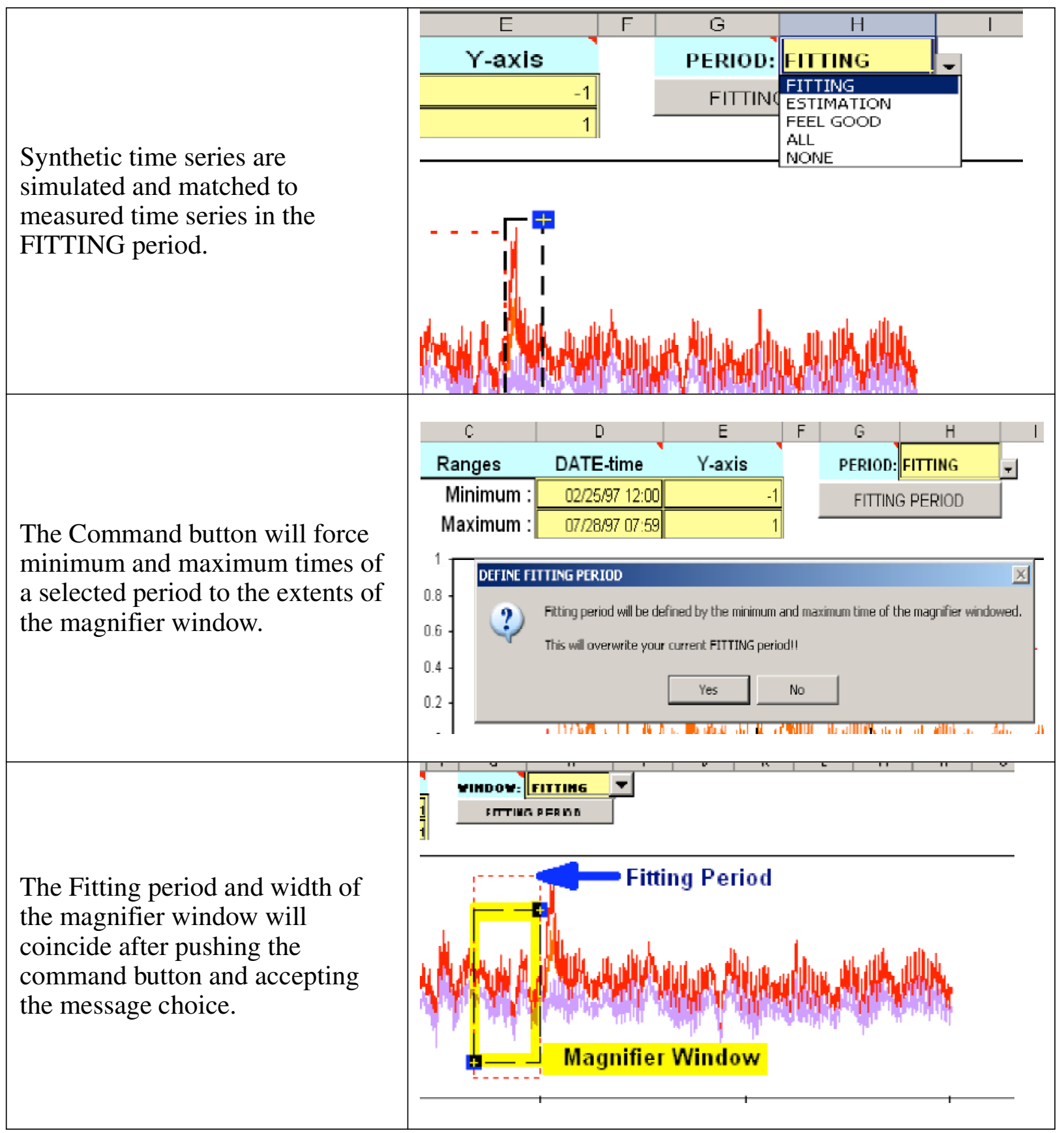




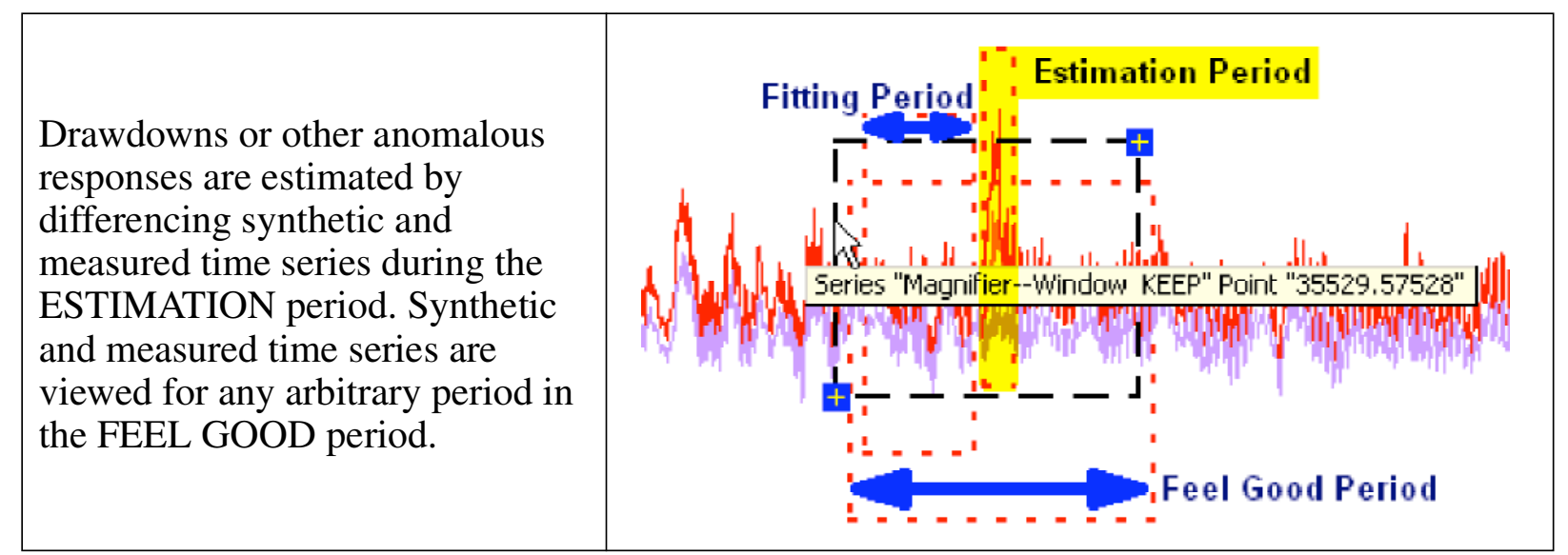

\section{DETREND Page}

Synthetic water levels are simulated and drawdowns are estimated from the DETREND page. Synthetic water levels can be simulated from a maximum of 24 time series, cells F33:AC33, plus a linear trend, cell D32. Raw, moving average, and differences between raw and moving averages of each user-defined series are available. Earth-tide and gravity-tide series are computed at 30-minute intervals from internal functions.

The estimation period in the Nevada example is from 5/1/1997 8:00 to 5/5/1997 8:00.

\section{Major Features of the DETREND Page}

Synthetic time series are simulated and drawdowns are estimated from the DETREND worksheet.

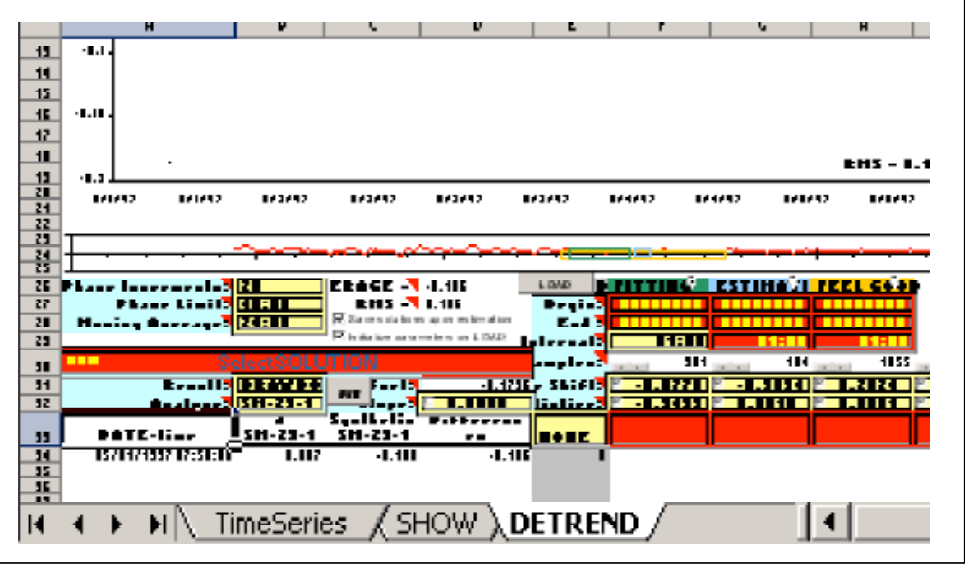




\section{PRIMARY SELECTIONS}

Assign phase-shift and moving average criteria, cells (B26:B28)

Refine time periods and subsampling, cells (F27:H29).

Select series to analyze, (B32).

Select components of synthetic time series, cells (F33:AC33).

Phase increment is the number of subdivisions between the minimum and maximum phaselimit.

Moving averages of original series are averaged over the userspecified period.

Begin is the first time sampled, row 27. End is the last time sampled, row 28. Interval defines the frequency of sub-sampling, row 29. All available data pairs will be sampled if an interval of 00:00 is specified.

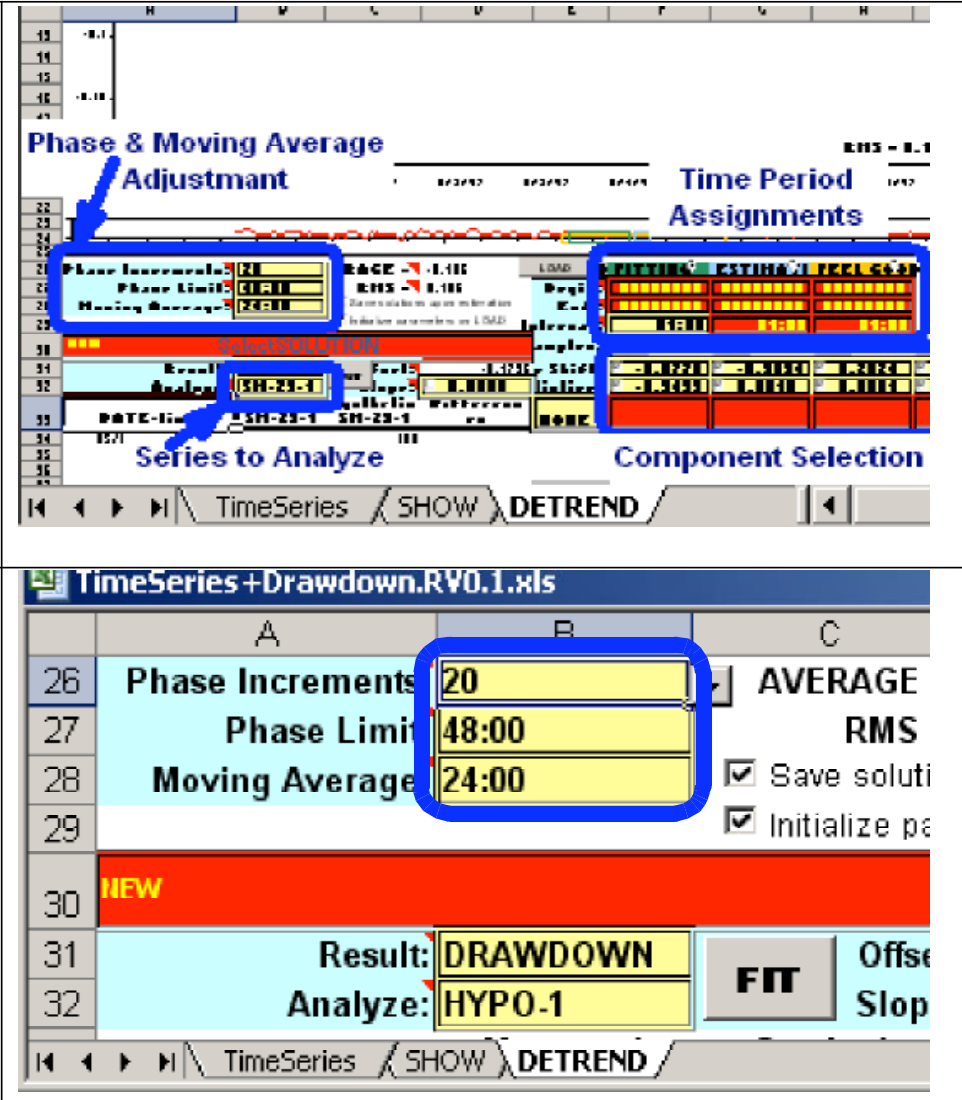

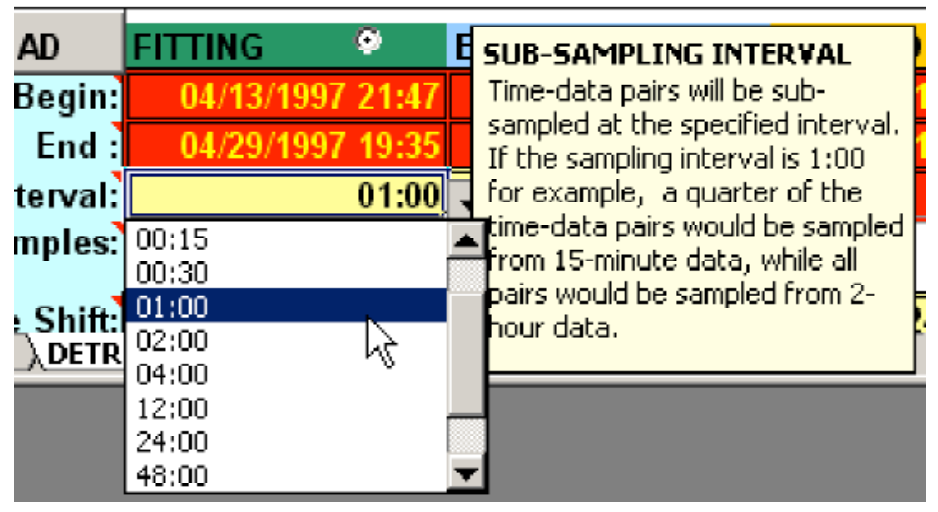




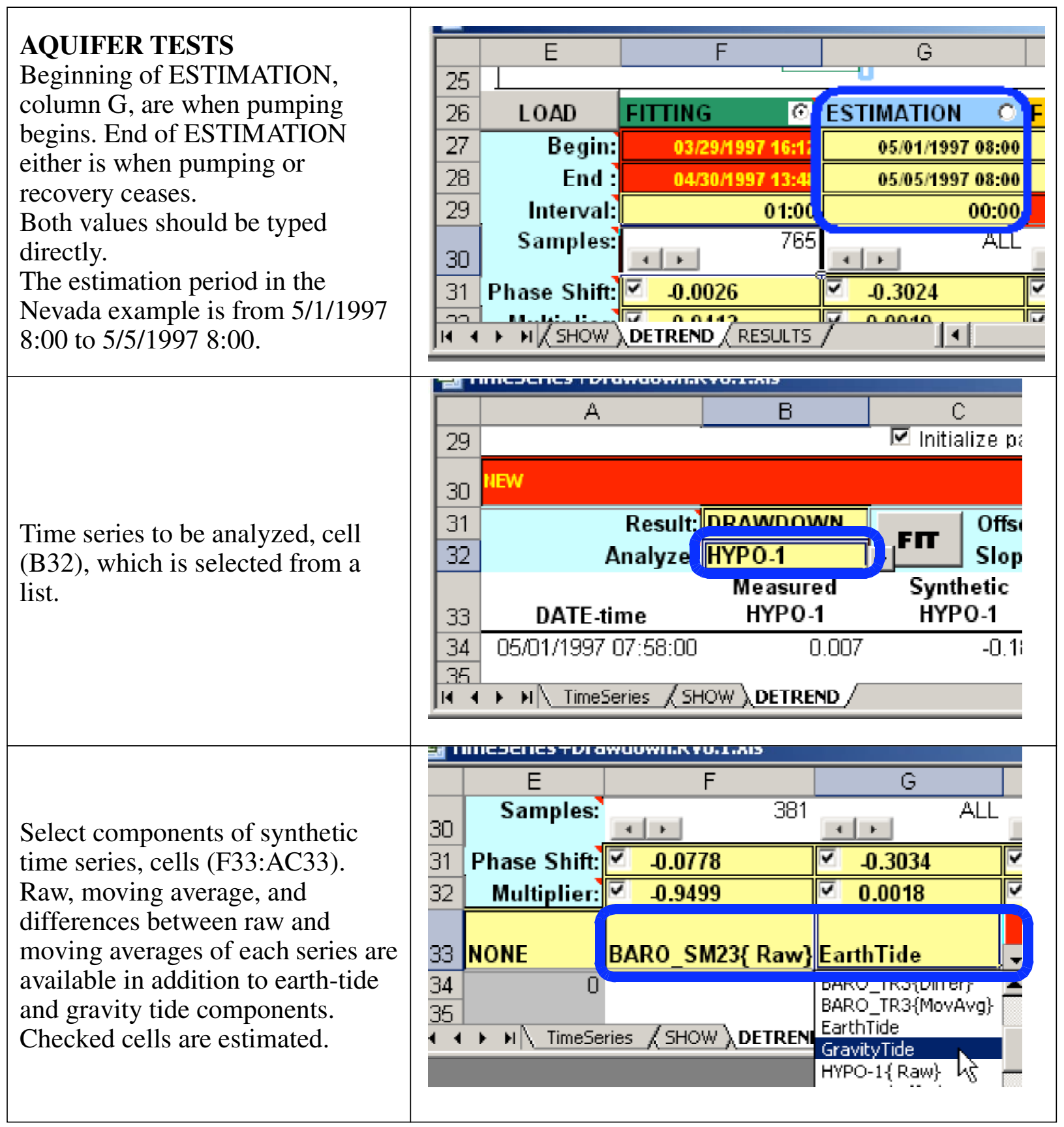

Synthetic time-series components are interpolated linearly from the user-supplied time series because fitting works when the functions are continuous. Subsets of the specified time series and their derivatives are copied to a hidden worksheet, TS3, when a new synthetic time series is loaded. Subsets are used because applying look-up functions to limited periods is faster.

Synthetic time series are estimated by fitting to measured values when an anomalous stress, such as pumping, is not present. Each component of a synthetic time series is modified with a multiplier that changes amplitude, row 32, and a constant that shifts phase, row 31. Amplitude and phase shift estimates typically are non-unique. This is not a limitation because synthetic time series are the result of interest, not the parameter estimates. 
Loading and Fitting Synthetic Series

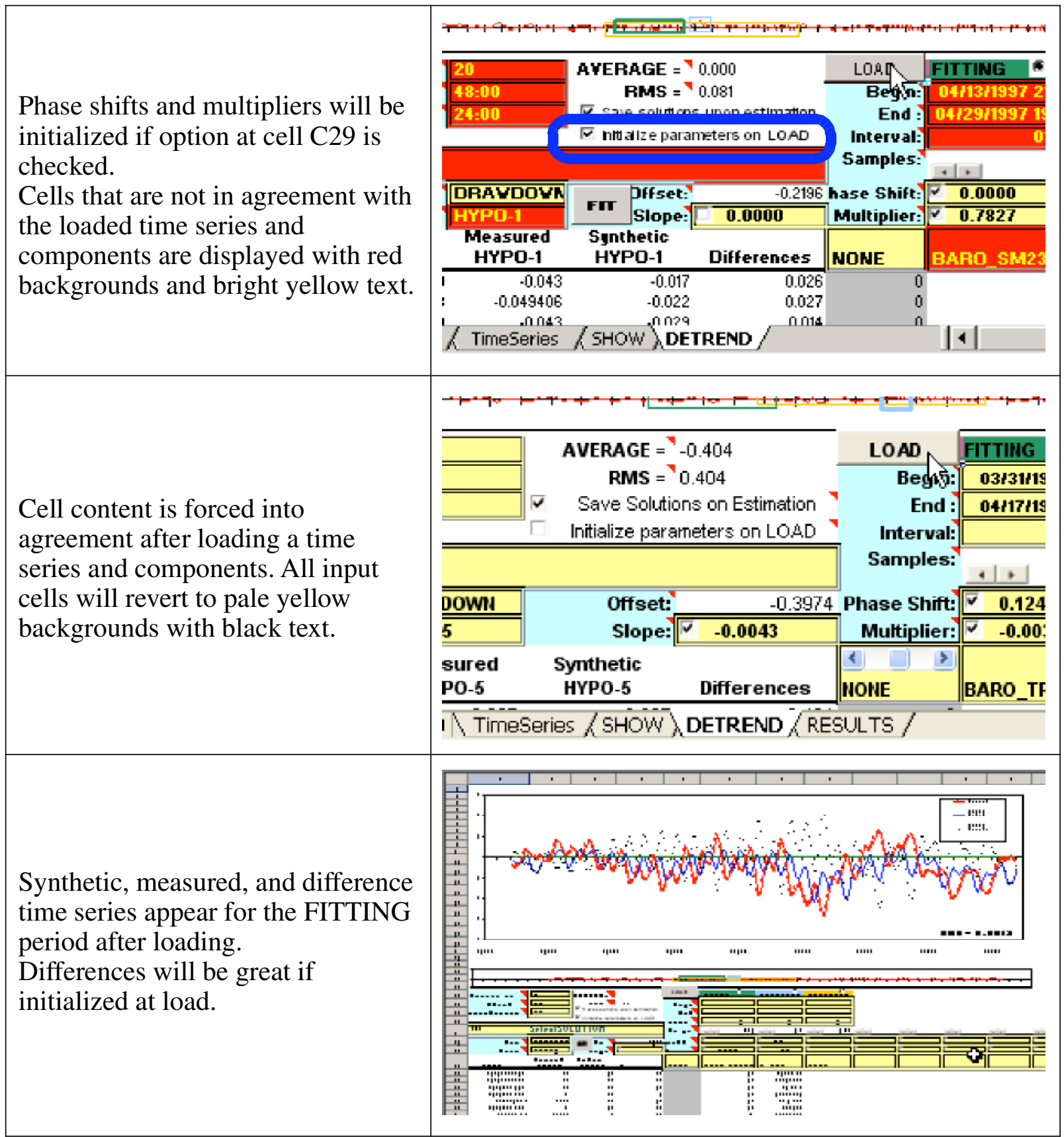




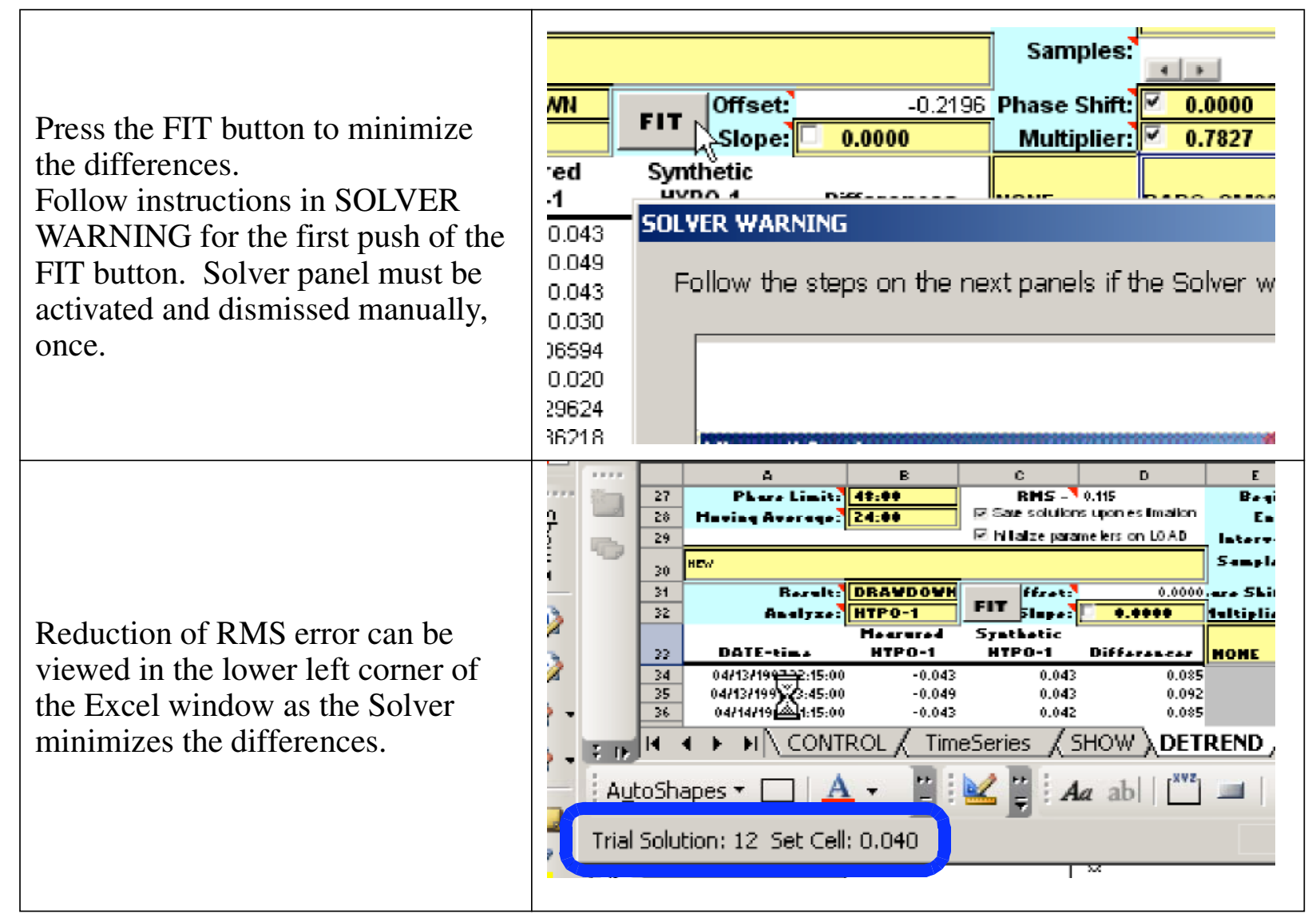

Drawdown estimates are differences between measured and synthetic water levels. The initial difference between measured and synthetic water levels at the beginning of a test is eliminated by subtracting the initial difference from all synthetic water levels.

Viewing Components and Estimating Drawdowns

View individual components by changing selection in cell E33. Phase shift of selected component can be adjusted with slider in cell E33.

Test effect of incremental phase change with the spin buttons in cells F30:AC30.

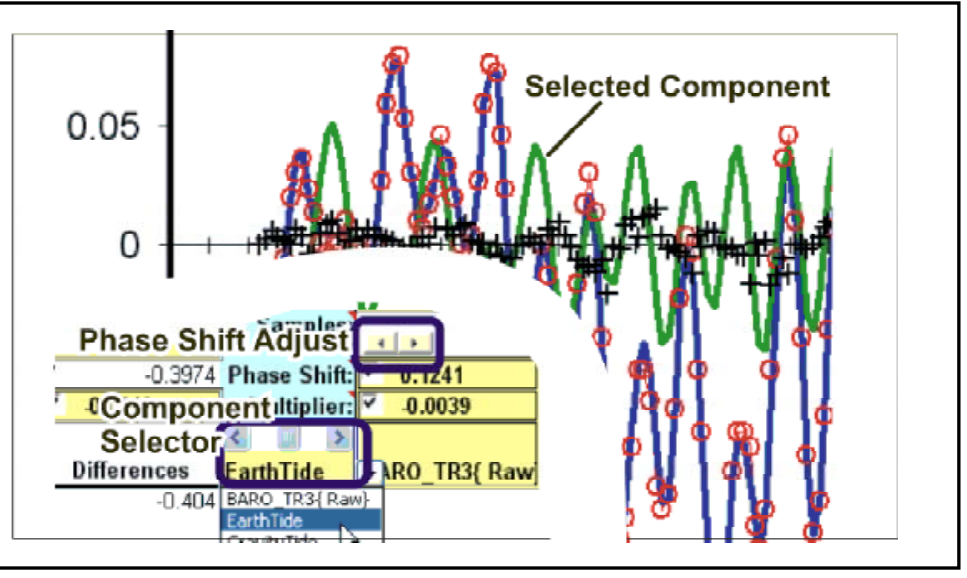




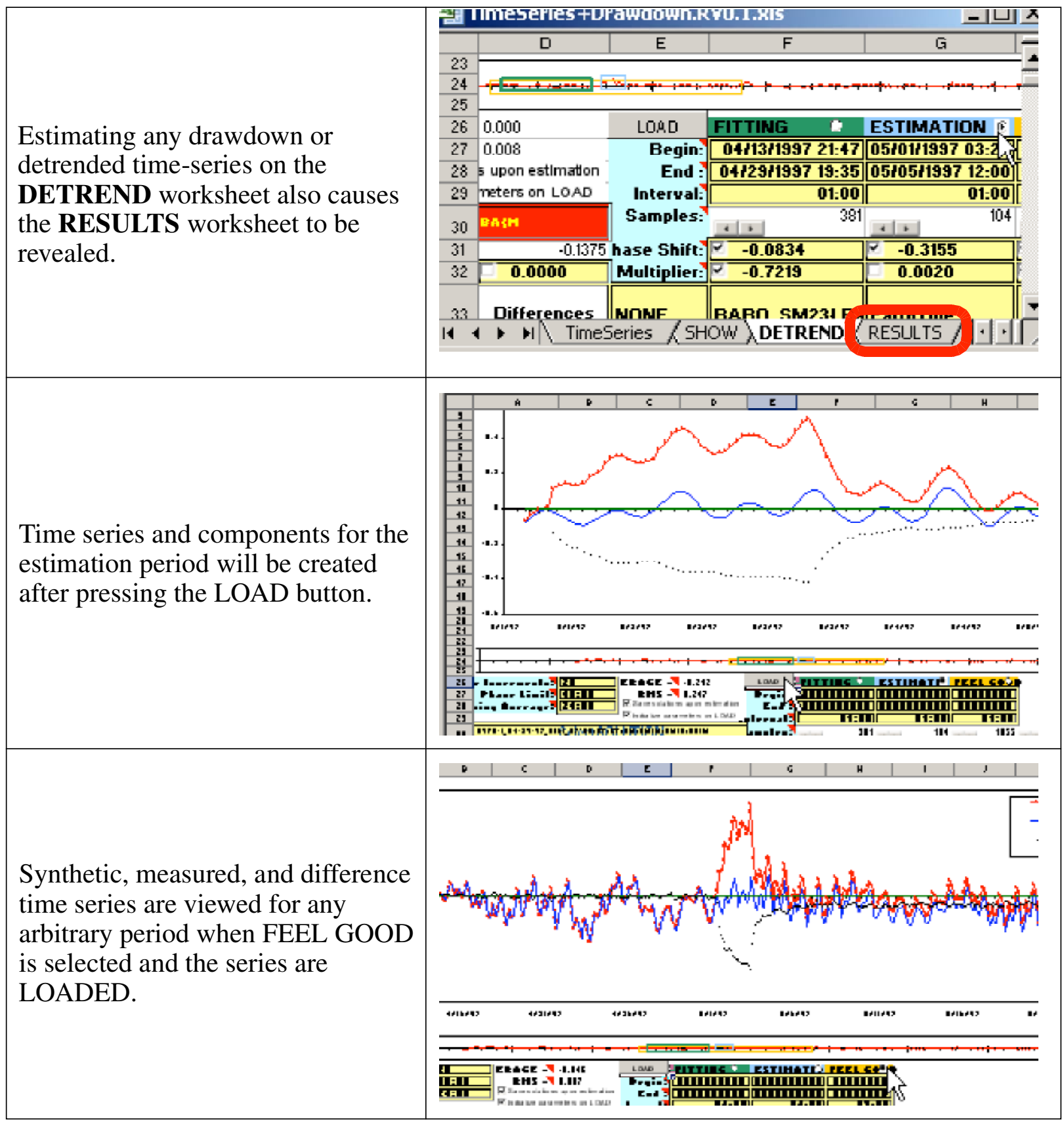

\section{RESULTS Page}

Drawdown estimates are viewed and exported to ASCII files from the RESULTS page. Drawdowns in each well can be exported to individual, tab-delimited ASCII files, which can be used by software used to calculate hydraulic properties. A well name, starting date, and starting time are written to the header of each drawdown file. Measurement date and time are written with each elapsed time-drawdown pair to help trace spurious responses.

Drawdown responses can be reduced further by averaging during sub-periods with an auxiliary program that is called from the FILTER DRAWDOWN command in cell A33. This program replaces drawdown estimates with a reduced set of time-averaged values. Drawdown and recovery components are divided into three sub-periods each for a total of six sub-periods. Drawdowns are averaged over user-specified intervals for each sub-period.

Drawdown and recovery responses in a well should be defined with less than 100 observations. A drawdown response of 1,000 observations can be represented equally well with fewer than 100 observations. Solution time is directly proportional to the number of observations when using an analytical model. Furthermore, plotted results become unintelligible with too many observations, regardless of the solution technique. 
These drawdown estimates are analyzed by copying directly from the spreadsheet application or writing the results to tabdelimited ASCII files.

Viewing, Filtering, and Exporting Drawdowns

Drawdowns are viewed on the

RESULTS worksheet.

Results can be written to tabdelimited, ASCII files or copied directly from the RESULTS worksheet.

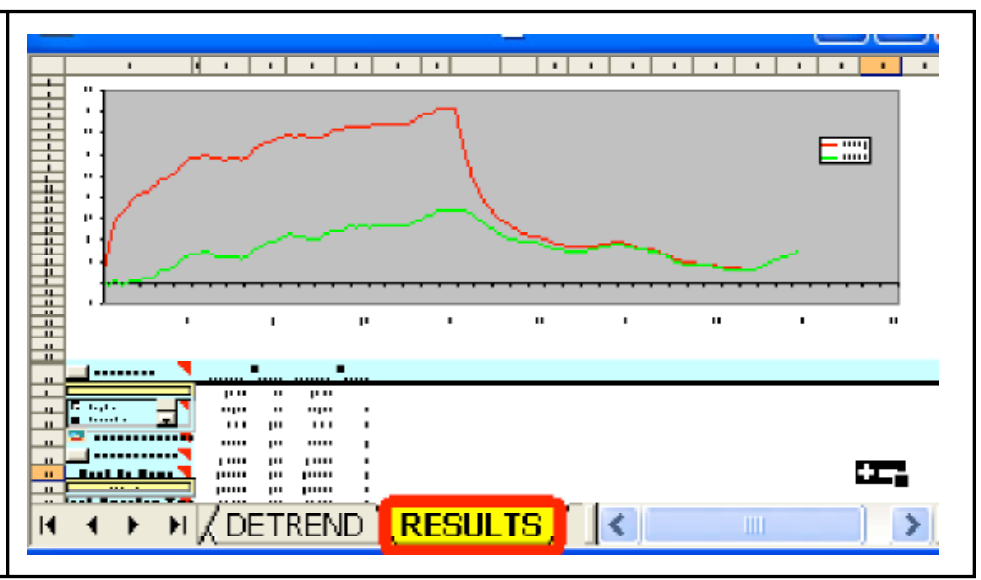

\section{OFFSET ADJUSTMENT}

Drawdowns can be adjusted with the spin button so the initial drawdowns are 0 . Check the series to adjust before pressing the spin button. Slide a drawdown series up until the minimum drawdown in the series equals 0 if "Noordbergum effect" caused negative drawdowns.

\section{FILTER DRAWDOWN}

Replaces drawdown estimates with a reduced set of time-averaged values. Drawdown and recovery components are divided into 3 subperiods each for a total of 6 subperiods. Drawdowns are averaged over user-specified intervals for each sub-period.

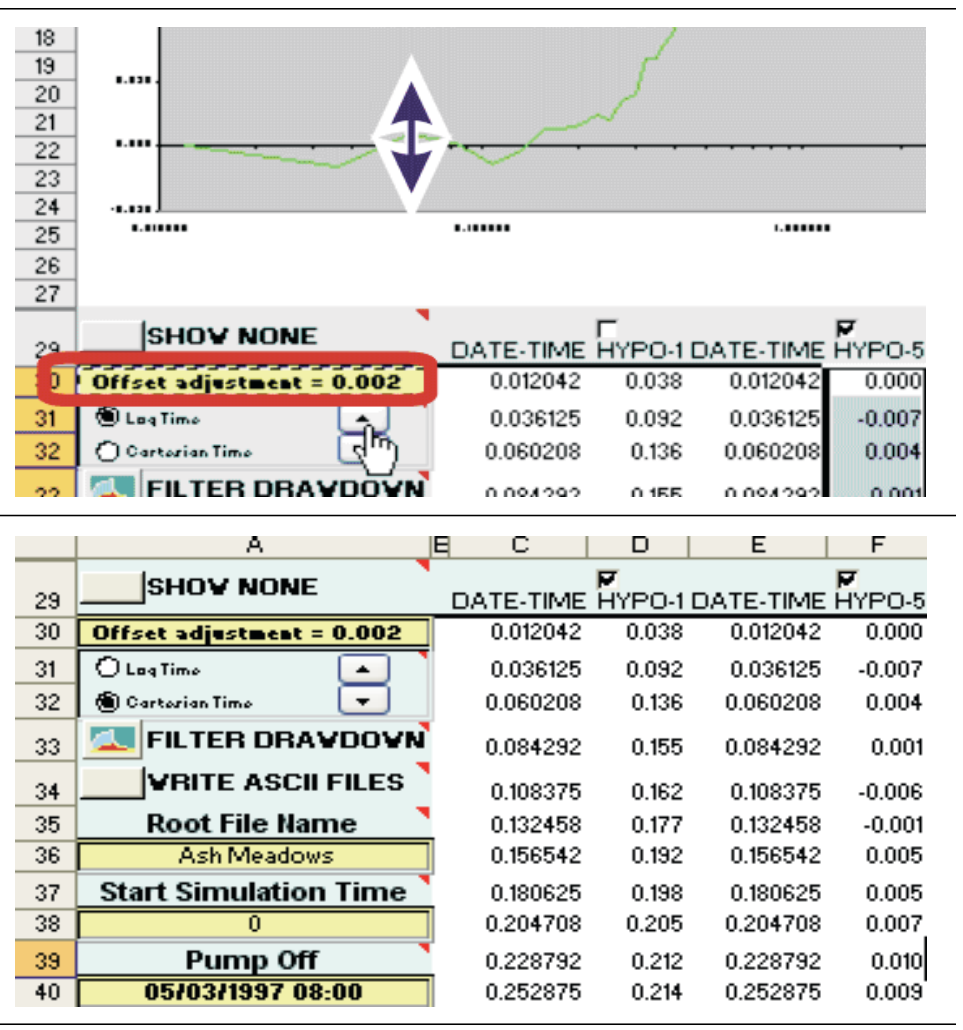




\begin{tabular}{|c|c|c|c|c|c|}
\hline \multirow{9}{*}{$\begin{array}{l}\text { Pump Off time should be typed } \\
\text { directly. } \\
\text { The pump-off time in the Nevada } \\
\text { example is } 5 / 3 / 19978: 00 \text {. }\end{array}$} & \multicolumn{2}{|c|}{$x<1=-1, \ldots+\cdots$} & 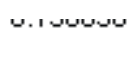 & $\begin{array}{ll}0.0 .1 \\
0.125\end{array}$ & 0.02 \\
\hline & 34 & WRITE ASCII FILES & 0290850 & 0166 & 0.04 \\
\hline & 35 & Root File Name & 0.333905 & 0.198 & 0.04 \\
\hline & 36 & Ash Meadows & 0.378350 & 0.210 & 0.05 \\
\hline & 37 & Start Simulation Time & 0.422794 & 0.217 & 0.08 \\
\hline & 38 & 0 & 0.467239 & 0.228 & 0.09 \\
\hline & 39 & Pump Off & 0.525572 & 0.250 & 0.12 \\
\hline & 40 & 05/03/1997 08:00 & 0.588072 & 0.256 & 0.14 \\
\hline & \begin{tabular}{|l}
41 \\
19 \\
119
\end{tabular} & $\begin{array}{l}\text { Pumping Time: } 52: 36 \mathrm{hr}: m i n \\
\text { 十 } \mathbf{M} / \text { SHOW } / \text { DETREND } 又 \mathbf{R}\end{array}$ & $\begin{array}{l}0.636683 \\
\text { ns } \\
\text { TS }\end{array}$ & $\begin{array}{l}0.283 \\
0 \text { רne }\end{array}$ & $\begin{array}{l}0.16 \\
0.19\end{array}$ \\
\hline & & 1. FILTER DRAWDOWI & 0.240850 & 0.125 & 0.02 \\
\hline & 34 & WRITE ASCII FILES & & 0.166 & 0.04 \\
\hline & 35 & Root File Name & 0.333905 & 0.198 & 0.04 \\
\hline Drawdown estimates are exported & 36 & Ash Meadows & 0.378350 & 0.210 & 0.05 \\
\hline by copying directly from the & 37 & Start Simulation Time & 0.422794 & 0.217 & 0.08 \\
\hline spreadsheet or writing the results to & 38 & 0 & 0.467239 & 0.228 & 0.09 \\
\hline tab-delimited, ASCII files. & 39 & Pump Off & 0.525572 & 0.250 & 0.12 \\
\hline & 40 & 05/03/1997 08:00 & 0.588072 & 0.256 & 0.14 \\
\hline & \begin{tabular}{|l|}
41 \\
99
\end{tabular} & Pumping Time: $52: 36 \mathrm{hr}$ :min & $\begin{array}{l}0.636683 \\
0070720\end{array}$ & $\begin{array}{l}0.283 \\
0.708\end{array}$ & $\begin{array}{l}0.16 \\
0.19\end{array}$ \\
\hline & in & - $M /$ /SHOW $/$ DETREND $>$ & TS & & \\
\hline
\end{tabular}

\section{Limitations}

The TimeSeries+Drawdown spreadsheet was developed for Microsoft Excel which limits the program. Individual time series are limited to about 65,000 data pairs and should be reduced to less than 32,000 data pairs after filtering. Time series with more than 32,000 data pairs will be truncated in charts because Excel limits each series in a graph to 32,000 pairs.

\section{References Cited}

Bower, D.R., 1983, Bedrock fracture parameters from the interpretation of well tides: Journal of Geophysical Research, v. 88, no. B6, p. 5025-5035.

Bredehoeft, J.D., 1967, Response of well-aquifer systems to earth tides: Journal of Geophysical Research, v. 72, no. 12, p. 3075-3087.

Clark, W.E., 1967, Computing the barometric efficiency of a well: Journal of the Hydraulics Division, American Society of Civil Engineers, v. 93, no. HY4, p. 93-98.
Erskine, A.D., 1991, The effect of tidal fluctuation on a coastal aquifer in the United Kingdom: Ground Water, v. 29, no. 4, p. 556-562.

Ferris, J.G., 1951, Cyclic fluctuations of water level as a basis for determining aquifer transmissibility: International Geodesy Geophysics Union, Association of Science Hydrology General Assembly, Brussels, v. 2, p. 148-155; duplicated in 1952 as U.S. Geological Survey Ground Water Note 1.

Ferris, J.G., Knowles, D.B., Brown, R.H., and Stallman, R.H., 1962, Theory of aquifer tests: USGS Series: U.S. Geological Survey Water Supply Paper 1536-E, 105 p.

Furbish, D.J., 1991, The response of water level in a well to a time series of atmospheric loading under confined conditions: Water Resources Research, v. 27, no. 4, p. 557-568.

Gregg, D.O., 1966, An analysis of ground-water fluctuations caused by ocean tides in Glynn County, Georgia: Ground Water, v. 4, no. 3, p. 24-32.

Halford, K.J., 1997, Effects of unsaturated zone on aquifer test analysis in a shallow-aquifer system: Ground Water, v. 35, no. 3, p. 512-522. 
Hanson, J.M., and Owen, L.B., 1982, Fracture orientation analysis by the solid earth tidal strain method: Presented at the 57th Annual Fall Technical Conference and Exhibition of the Society of Petroleum Engineers of AIME, American Institute of Mechanical Engineers, New Orleans, Louisiana, September 26-29, 1982.

Harrison, J.C., 1971, New computer programs for the calculation of Earth tides: National Oceanic and Atmospheric Administration/University of Colorado, Cooperative Institute for Research in Environmental Sciences, 30 p.

Hsieh, P.A., Bredehoeft, J.D., and Rojstaczer, S.A., 1988, Response of well-aquifer systems to earth tides: Problem revisited: Water Resources Research, v. 24, no. 3, p. 468472 .

Jacob, C.E., 1940, On the flow of water in an elastic artesian aquifer: American Geophysical Union Transactions, part 2, p. 574-586; duplicated in 1953 as U.S. Geological Survey Ground Water Note 8.

Jiao, J.J., and Tang, Z., 1999, An analytic solution of groundwater response to tidal fluctuation in a leaky confined aquifer: Water Resources Research, v. 35, no. 3, p. 747-751.

Kruseman, G.P., and DeRidder, N.A., 1990, Analysis and evaluation of pumping test data, Publication 47, (2nd ed.): Wageningen, The Netherlands, International Institute for Land Reclamation and Improvement, $370 \mathrm{p}$.

Li, H., and Jiao, J.J., 2001, Tide-induced groundwater fluctuation in a coastal leaky confined aquifer system extending under the sea: Water Resources Research, v. 37, no. 5, p. 1165-1171.

Marine, I.W., 1975, Water level fluctuations due to earth tides in a well pumping from slightly fractured rock: Water Resources Research, v. 11, no. 1, p. 165-173.

Melchior, P., 1964, Earth tides, in Odishaw, H., ed., Research in Geophysics, v. 2: Cambridge, Massachusetts, Massachusetts Institute of Technology Press, p. 183-193.

Merritt, M.L., 2004, Estimating hydraulic properties of the Floridan aquifer system by analysis of earth-tide, oceantide, and barometric effects, Collier and Hendry Counties, Florida: U.S. Geological Survey Water-Resources Investigations Report 03-4267, 70 p.

Narasimhan, T.N., Kanehiro, B.Y., and Witherspoon, P.A., 1984, Interpretation of earth tide responses of three deep, confined aquifers: Journal of Geophysical Research, v. 89, no. B3, p. 1913-1924.

O'Reilly, A.M., 1998, Hydrogeology and simulation of the effects of reclaimed-water application in west Orange and southeast Lake Counties, Florida: U.S. Geological Survey Water-Resources Investigations Report 97-4199, 91 p.
Risser, D.W., and Bird, P.H., 2003, Aquifer tests and simulation of ground-water flow in Triassic sedimentary rocks near Colmar, Bucks, and Montgomery Counties, Pennsylvania: U.S. Geological Survey Water-Resources Investigations Report 03-4159, 73 p.

Robinson, E.S., and Bell, R.T., 1971, Tides in confined wellaquifer systems: Journal of Geophysical Research, v. 76, no. 8, p. $1857-1869$.

Rojstaczer, S., 1988, Determination of fluid flow properties from the response of water levels in wells to atmospheric loading: Water Resources Research, v. 24, no. 11, p. 19271938.

Rojstaczer, S., and Agnew, D.C., 1989, The influence of formation material properties on the response of water levels in wells to earth tides and atmospheric loading: Journal of Geophysical Research, v. 94, no. B9, p. 12403-12411.

Rojstaczer, S., and Riley, F.S., 1990, Response of the water level in a well to earth tides and atmospheric loading under unconfined conditions: Water Resources Research, v. 26, no. 8, p. 1803-1817.

Rutledge, A.T., 1985, Use of double-mass curves to determine drawdown in a long-term aquifer test in north-central Volusia County, Florida: U.S. Geological Survey WaterResources Investigations Report 84-4309, 29 p.

Theis, C.V., 1935, The relation between the lowering of the piezometric surface and the rate and duration of discharge of a well using ground water storage: Transactions of the American Geophysical Union, v. 16, p. 519-524.

van der Kamp, G., 1972, Tidal fluctuations in a confined aquifer extending under the sea: International Geological Congress, v. 24, no. 11, p. 101-106.

van der Kamp, G., and Gale, J.E., 1983, Theory of earth tide and barometric effects in porous formations with compressible grains: Water Resources Research, v. 19, no. 2, p. 538-544.

Verruijt, A., 1969, Elastic storage of aquifers, in De Wiest, R.J.M., ed., Flow Through Porous Media: New York, Academic Press, p. 331-376.

Weeks, E.P., 1979, Barometric fluctuations in wells tapping deep unconfined aquifers: Water Resources Research, v. 15, no. 5, p. 1167-1176.

Wolff, R.G., 1970, Relationship between horizontal strain near a well and reverse water level fluctuation: Water Resources Research, v. 6, p. 1721-1728. 


\section{Appendix}

\section{Step-by-Step Instructions for Nevada Example}

The spreadsheets TimeSeries+Drawdown.V1.0.xls, NV_WLsource.xls, and FilterTEMPLATE.AQUSGS are referred in the step-by-step instructions. TimeSeries+Drawdown.V1.0.xls and NV_WLsource.xls are opened directly as conventional Excel files. FilterTEMPLATE.AQUSGS is a specialized tool for filtering drawdown estimates that is called from the TimeSeries+Drawdown.V1.0.xls workbook. Users should not open FilterTEMPLATE.AQUSGS directly.

Instructions are provided in a five column table. The first three columns identify the workbook, page, and cell that should be selected for a specific step. User actions, such as copy, paste, slide, or press, are specified in the fourth column. Limited descriptions of spreadsheet responses to the user actions are reported in column 5. Row colors alternately are changed between white and yellow to indicate a change between pages or workbooks.

\begin{tabular}{|c|c|c|c|c|}
\hline \multicolumn{5}{|c|}{ Step-by-Step Instructions for Nevada Example. } \\
\hline WORKBOOK & Page & Cell & Action & Description \\
\hline NV_WLsource.xls & NV & B1:B4 & Edit $>$ Copy Range & Define name and location of site \\
\hline TimeSeries+Drawdown.V1.0.xls & TimeSeries & B1 & Edit $>$ Paste Special ... Values & \\
\hline NV_WLsource.xls & NV & A6:I20015 & Edit $>$ Copy Range & Define time-series to be analyzed \\
\hline TimeSeries+Drawdown.V1.0.xls & TimeSeries & B12 & Edit $>$ Paste Special ... Values & \\
\hline TimeSeries+Drawdown.V1.0.xls & TimeSeries & A14 & Press "Initialize Series" button & $\begin{array}{l}\text { Catalog available time series, initialize time-series } \\
\text { filtering process, and reveal the following page, } \\
\text { SHOW }\end{array}$ \\
\hline TimeSeries+Drawdown.V1.0.xls & TimeSeries & B5 & Change settings in Row 5 of the sheet TimeSeries & $\begin{array}{l}\text { Follow instructions in the wizard. Change settings on } \\
\text { the sheet TimeSeries }\end{array}$ \\
\hline TimeSeries+Drawdown.V1.0.xls & TimeSeries & & $\begin{array}{l}\text { Press "FILTER" button on the "FILTER EXPLANATION \& } \\
\text { QUERY" form }\end{array}$ & \\
\hline TimeSeries+Drawdown.V1.0.xls & TimeSeries & & Activate "SHOW" page & \\
\hline TimeSeries+Drawdown.V1.0.xls & SHOW & B11 & Check box and activate "TR-3" hydrograph & Plot hydrograph record \\
\hline TimeSeries+Drawdown.V1.0.xls & SHOW & B9 & Check box and activate "HYPO-1" hydrograph & Plot hydrograph record \\
\hline TimeSeries+Drawdown.V1.0.xls & SHOW & & $\begin{array}{l}\text { Grab upper, right handle of magnifier window in the upper plot. } \\
\text { Change from }(7 / 28 / 9707: 59: 57,6.10) \text { to } \sim(3 / 18 / 97,-19.4) \text {. }\end{array}$ & $\begin{array}{l}\text { Adjust magnifier window to view water levels over a } \\
\text { three week period. }\end{array}$ \\
\hline TimeSeries+Drawdown.V1.0.xls & SHOW & B1 & Magnifier window should be about 20 days wide & \\
\hline TimeSeries+Drawdown.V1.0.xls & SHOW & B2 & Magnifier window should be about $1 \mathrm{ft}$ high & \\
\hline TimeSeries+Drawdown.V1.0.xls & SHOW & $\mathrm{E} 2$ & Change cell E2 to -1 & \\
\hline TimeSeries+Drawdown.V1.0.xls & SHOW & E3 & Change cell E3 to +1 & \\
\hline TimeSeries+Drawdown.V1.0.xls & SHOW & B23 & $\begin{array}{l}\text { Move slider on vertical slide bar. Click again if cells E2:E3 } \\
\text { remain orange. }\end{array}$ & Magnify periods of record graphically. \\
\hline
\end{tabular}




\begin{tabular}{|c|c|c|c|c|}
\hline \multicolumn{5}{|c|}{ Step-by-Step Instructions for Nevada Example-Continued } \\
\hline WORKBOOK & Page & Cell & Action & Description \\
\hline TimeSeries+Drawdown.V1.0.xls & SHOW & $\mathrm{C} 22$ & $\begin{array}{l}\text { Move slider on horizontal slide bar. Click again if cells D2:D3 } \\
\text { remain orange. }\end{array}$ & \\
\hline TimeSeries+Drawdown.V1.0.xls & SHOW & $\mathrm{F} 22$ & $\begin{array}{l}\text { Upper, right handle of magnifier window should be about } \\
\text { 4/30/97 after adjusting the slider bar }\end{array}$ & \\
\hline TimeSeries+Drawdown.V1.0.xls & SHOW & $\mathrm{H} 1$ & Change to the FITTING selection & \\
\hline TimeSeries+Drawdown.V1.0.xls & SHOW & G2 & Press “FITTING PERIOD” button & Define a "FITTING PERIOD" graphically. \\
\hline TimeSeries+Drawdown.V1.0.xls & SHOW & B1 & Adjust magnifier window in upper plot to be about 4-d wide. & \\
\hline TimeSeries+Drawdown.V1.0.xls & SHOW & & $\begin{array}{l}\text { Move slider on horizontal slide bar so left side of magnifier } \\
\text { window is near 5/1/97 8:00 AM }\end{array}$ & \\
\hline TimeSeries+Drawdown.V1.0.xls & SHOW & H1 & Change to the ESTIMATION selection & \\
\hline TimeSeries+Drawdown.V1.0.xls & SHOW & I1 & Select an unused cell to force selection button to change & \\
\hline TimeSeries+Drawdown.V1.0.xls & SHOW & G2 & Press “ESTIMATION PERIOD” button & $\begin{array}{l}\text { Define an "ESTIMATION PERIOD" graphically } \\
\text { which is not a good idea for aquifer test analyses. }\end{array}$ \\
\hline TimeSeries+Drawdown.V1.0.xls & SHOW & B1 & Adjust magnifier window in upper plot to be about 40 -d wide. & \\
\hline TimeSeries+Drawdown.V1.0.xls & SHOW & & $\begin{array}{l}\text { Move slider on horizontal slide bar so left side of magnifier } \\
\text { window is near } 4 / 13 / 97\end{array}$ & \\
\hline TimeSeries+Drawdown.V1.0.xls & SHOW & $\mathrm{H} 1$ & Change to the FEEL GOOD selection & \\
\hline TimeSeries+Drawdown.V1.0.xls & SHOW & I1 & Select an unused cell to force selection button to change & \\
\hline TimeSeries+Drawdown.V1.0.xls & SHOW & G2 & Press “FEEL GOOD” button & $\begin{array}{l}\text { Graphically define a period for viewing both fitting } \\
\text { and estimation periods simultaneously. }\end{array}$ \\
\hline TimeSeries+Drawdown.V1.0.xls & SHOW & & Activate "DETREND" page & \\
\hline TimeSeries+Drawdown.V1.0.xls & DETREND & $\mathrm{G} 27$ & Change cell G27 to 5/1/97 8:00 & Specify beginning of aquifer test \\
\hline TimeSeries+Drawdown.V1.0.xls & DETREND & G28 & Change cell G28 to 5/5/97 8:00 & $\begin{array}{l}\text { Specify end of recovery period to be analyzed. End of } \\
\text { aquifer test is specified in cell A40 on the RE- } \\
\text { SULTS page. }\end{array}$ \\
\hline TimeSeries+Drawdown.V1.0.xls & DETREND & F29 & Change cell F29 to 2 hours & \\
\hline TimeSeries+Drawdown.V1.0.xls & DETREND & G29 & Change cell G29 to 0 hours & \\
\hline TimeSeries+Drawdown.V1.0.xls & DETREND & $\mathrm{H} 29$ & Change cell $\mathrm{H} 29$ to 4 hours & \\
\hline TimeSeries+Drawdown.V1.0.xls & DETREND & F26 & Select the "FITTING" radio button in cell F26 & \\
\hline TimeSeries+Drawdown.V1.0.xls & DETREND & B32 & Select cell B32 and change to HYPO-1 & Define components of the synthetic water levels. \\
\hline TimeSeries+Drawdown.V1.0.xls & DETREND & F33 & Select cell F33 and change to BARO_SM23\{ Raw $\}$ & \\
\hline TimeSeries+Drawdown.V1.0.xls & DETREND & G33 & Select cell G33 and change to EarthTide & \\
\hline TimeSeries+Drawdown.V1.0.xls & DETREND & $\mathrm{H} 33$ & Select cell H33 and change to GravityTide & \\
\hline
\end{tabular}

TimeSeries+Drawdown.V1.0.xls TimeSeries+Drawdown.V1.0.xl 


\begin{tabular}{|c|c|c|c|c|}
\hline \multicolumn{5}{|c|}{ Step-by-Step Instructions for Nevada Example-Continued } \\
\hline WORKBOOK & Page & Cell & Action & Description \\
\hline TimeSeries+Drawdown.V1.0.xls & DETREND & $\mathrm{I} 33$ & Select cell I33 and change to SM-23-1\{ Raw $\}$ & \\
\hline TimeSeries+Drawdown.V1.0.xls & DETREND & $\mathrm{J} 33$ & Select cell J33 and change to SM-23-1\{Differ $\}$ & \\
\hline TimeSeries+Drawdown.V1.0.xls & DETREND & K33 & Select cell K33 and change to SM-23-1\{MovAvg $\}$ & \\
\hline TimeSeries+Drawdown.V1.0.xls & DETREND & E26 & Press “LOAD” button & $\begin{array}{l}\text { Creates equations for each time-series component that } \\
\text { was selected. These equations are limited to the } \\
\text { fitting period plus the maximum phase shift. }\end{array}$ \\
\hline TimeSeries+Drawdown.V1.0.xls & DETREND & $\mathrm{C} 31$ & Press "FIT" button & Initiates SOLVER \\
\hline TimeSeries+Drawdown.V1.0.xls & DETREND & & $\begin{array}{l}\text { Dismiss SOLVER warning. Call SOLVER and dismiss. SOLV- } \\
\text { ER is called from Tools }>\text { Solver }\end{array}$ & \\
\hline TimeSeries+Drawdown.V1.0.xls & DETREND & $\mathrm{C} 31$ & Press "FIT" button & Initiates SOLVER \\
\hline TimeSeries+Drawdown.V1.0.xls & DETREND & G26 & Select the "ESTIMATION" radio button in cell G26 & $\begin{array}{l}\text { Creates equations for each time-series component that } \\
\text { was selected. These equations are limited to the } \\
\text { estimation period plus the maximum phase shift. } \\
\text { Drawdowns also are estimated and written to the } \\
\text { RESULTS page. }\end{array}$ \\
\hline TimeSeries+Drawdown.V1.0.xls & DETREND & B32 & Select cell B32 and change to HYPO-5 & Changes site to analyze. \\
\hline TimeSeries+Drawdown.V1.0.xls & DETREND & F26 & Select the "FITTING" radio button in cell F26 & \\
\hline TimeSeries+Drawdown.V1.0.xls & DETREND & E26 & Press “LOAD” button & $\begin{array}{l}\text { Creates equations for each time-series component that } \\
\text { was selected. These equations are limited to the } \\
\text { fitting period plus the maximum phase shift. }\end{array}$ \\
\hline TimeSeries+Drawdown.V1.0.xls & DETREND & $\mathrm{C} 31$ & Press "FIT" button & Initiates SOLVER \\
\hline TimeSeries+Drawdown.V1.0.xls & DETREND & G26 & Select the "ESTIMATION" radio button in cell G26 & $\begin{array}{l}\text { Creates equations for each time-series component that } \\
\text { was selected. These equations are limited to the } \\
\text { estimation period plus the maximum phase shift. } \\
\text { Drawdowns also are estimated and written to the } \\
\text { RESULTS page. }\end{array}$ \\
\hline TimeSeries+Drawdown.V1.0.xls & DETREND & & Activate "RESULTS" page & \\
\hline TimeSeries+Drawdown.V1.0.xls & RESULTS & A29 & Press "SHOW ALL" to see drawdowns & \\
\hline TimeSeries+Drawdown.V1.0.xls & RESULTS & A40 & $\begin{array}{l}\text { Change cell A40 to 5/3/97 8:00AM. Pumping time in cell A41 } \\
\text { should read 48:00 hr:min }\end{array}$ & Specify when pumping ceased for the aquifer test. \\
\hline TimeSeries+Drawdown.V1.0.xls & RESULTS & A31 & Toggle radio button to Log time & \\
\hline TimeSeries+Drawdown.V1.0.xls & RESULTS & A32 & Toggle radio button to Cartesian time & \\
\hline TimeSeries+Drawdown.V1.0.xls & RESULTS & A33 & Press “FILTER DRAWDOWN” button. & $\begin{array}{l}\text { Transfers drawdown estimates to another spreadsheet } \\
\text { for reducing drawdowns by averaging over user- } \\
\text { specified intervals. }\end{array}$ \\
\hline
\end{tabular}


Step-by-Step Instructions for Nevada Example-Continued

\begin{tabular}{|c|c|c|c|c|}
\hline WORKBOOK & Page & Cell & Action & Description \\
\hline FilterTEMPLATE.AQUSGS & SEE & F26 & Change from 20 to 10 & \\
\hline FilterTEMPLATE.AQUSGS & SEE & $\mathrm{F} 27$ & Change from 20 to 30 & \\
\hline FilterTEMPLATE.AQUSGS & SEE & F28 & Change from 20 to 30 & \\
\hline FilterTEMPLATE.AQUSGS & SEE & F29 & Change from 10 to 0 & \\
\hline FilterTEMPLATE.AQUSGS & SEE & F30 & Change from 10 to 15 & \\
\hline FilterTEMPLATE.AQUSGS & SEE & $\mathrm{I} 25$ & Check "Logarithmic Axis" & \\
\hline FilterTEMPLATE.AQUSGS & SEE & $\mathrm{C} 26$ & Adjust spin button until End Time in cell E26 is 0d 03:09:00 & \\
\hline FilterTEMPLATE.AQUSGS & SEE & $\mathrm{C} 27$ & Adjust spin button until End Time in cell E27 is 0d 23:59:00 & \\
\hline FilterTEMPLATE.AQUSGS & SEE & $\mathrm{I} 25$ & Check "Show recovery after pump off" & \\
\hline FilterTEMPLATE.AQUSGS & SEE & $\mathrm{C} 29$ & Adjust spin button until End Time in cell E29 is $2 \mathrm{~d}$ 00:27:00 & \\
\hline FilterTEMPLATE.AQUSGS & SEE & $\mathrm{C} 30$ & Adjust spin button until End Time in cell E30 is 2 d 14:30:29 & \\
\hline FilterTEMPLATE.AQUSGS & SEE & $\mathrm{I} 25$ & Uncheck "Show recovery after pump off" & \\
\hline FilterTEMPLATE.AQUSGS & SEE & $\mathrm{I} 25$ & Uncheck "Logarithmic Axis" & \\
\hline FilterTEMPLATE.AQUSGS & SEE & I 26 & Press "Filter Drawdowns" & $\begin{array}{l}\text { Drawdowns are averaged across equally spaced inter- } \\
\text { vals in each sub-period. }\end{array}$ \\
\hline FilterTEMPLATE.AQUSGS & SEE & $\mathrm{I} 25$ & Check "Logarithmic Axis" & \\
\hline FilterTEMPLATE.AQUSGS & SEE & $\mathrm{I} 26$ & Press "Filter Drawdowns" & $\begin{array}{l}\text { Drawdowns are averaged across log-equally spaced } \\
\text { intervals in each sub-period. }\end{array}$ \\
\hline FilterTEMPLATE.AQUSGS & SEE & $\mathrm{I} 25$ & Uncheck "Logarithmic Axis" & \\
\hline FilterTEMPLATE.AQUSGS & SEE & I 26 & Press "Filter Drawdowns" & $\begin{array}{l}\text { Drawdowns are averaged across equally spaced inter- } \\
\text { vals in each sub-period. }\end{array}$ \\
\hline FilterTEMPLATE.AQUSGS & SEE & D32 & Select "HYPO-5" from pulldown menu & $\begin{array}{l}\text { View filtered and unfiltered drawdowns in well } \\
\text { HYPO-5 }\end{array}$ \\
\hline FilterTEMPLATE.AQUSGS & SEE & D32 & Select "HYPO-1" from pulldown menu & $\begin{array}{l}\text { View filtered and unfiltered drawdowns in well } \\
\text { HYPO-1 }\end{array}$ \\
\hline FilterTEMPLATE.AQUSGS & SEE & $\mathrm{I} 28$ & Press "Return Filtered Drawdowns" & $\begin{array}{l}\text { Unfiltered drawdowns on the RESULTS page in the } \\
\text { TimeSeries+Drawdown.V1.0.xls workbook are } \\
\text { cleared and replaced with the filtered drawdowns. }\end{array}$ \\
\hline TimeSeries+Drawdown.V1.0.xls & RESULTS & A29 & Press "SHOW ALL" 1-2 times until drawdowns are visible & \\
\hline TimeSeries+Drawdown.V1.0.xls & RESULTS & A34 & Press "WRITE ASCII FILES" & $\begin{array}{l}\text { The files "Ash Meadows_HYPO-1.txt" and "Ash } \\
\text { Meadows_HYPO-5.txt" will be created. }\end{array}$ \\
\hline
\end{tabular}





\section{疍}

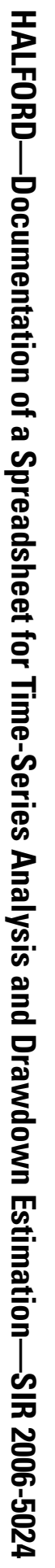

